\title{
Review
}

\section{TCR Recognition of Peptide-MHC-I: Rule Makers and Breakers}

\author{
Christopher Szeto ${ }^{1}$, Christian A. Lobos ${ }^{1}$, Andrea T. Nguyen ${ }^{1}$ and Stephanie Gras ${ }^{1,2, *(1)}$ \\ 1 Department of Biochemistry and Molecular Biology, Biomedicine Discovery Institute, Monash University, \\ Clayton, VIC 3800, Australia; chris.szeto@monash.edu (C.S.); christian.lobos@monash.edu (C.A.L.); \\ andrea.nguyen@monash.edu (A.T.N.) \\ 2 Australian Research Council Centre of Excellence for Advanced Molecular Imaging, Monash University, \\ Clayton, VIC 3800, Australia \\ * Correspondence: stephanie.gras@monash.edu
}

check for updates

Citation: Szeto, C.; Lobos, C.A.; Nguyen A.T.; Gras, S. TCR Recognition of PeptideMHC-I: Rule Makers and Breakers. Int. J. Mol. Sci. 2021, 22, 68. https://dx.doi. org/10.3390/ijms22010068

Received: 1 November 2020 Accepted: 21 December 2020 Published: 23 December 2020

Publisher's Note: MDPI stays neutral with regard to jurisdictional claims in published maps and institutional affiliations.

Copyright: () 2020 by the authors. Licensee MDPI, Basel, Switzerland. This article is an open access article distributed under the terms and conditions of the Creative Commons Attribution (CC BY) license (https: / creativecommons.org/ licenses/by/4.0/).

\begin{abstract}
T$ cells are a critical part of the adaptive immune system that are able to distinguish between healthy and unhealthy cells. Upon recognition of protein fragments (peptides), activated T cells will contribute to the immune response and help clear infection. The major histocompatibility complex (MHC) molecules, or human leukocyte antigens (HLA) in humans, bind these peptides to present them to T cells that recognise them with their surface T cell receptors (TCR). This recognition event is the first step that leads to $\mathrm{T}$ cell activation, and in turn can dictate disease outcomes. The visualisation of TCR interaction with pMHC using structural biology has been crucial in understanding this key event, unravelling the parameters that drive this interaction and their impact on the immune response. The last five years has been the most productive within the field, wherein half of current unique TCR-pMHC-I structures to date were determined within this time. Here, we review the new insights learned from these recent TCR-pMHC-I structures and their impact on T cell activation.
\end{abstract}

Keywords: human leukocyte antigen (HLA); MHC class I; peptide antigens; TCR binding; $\alpha \beta$ TCR; $\delta \beta$ TCR; $\gamma \delta$ TCR

\section{Overview of Structures and Status}

$\mathrm{T}$ cells use their surface receptor, called $\mathrm{T}$ cell receptor or TCR, to recognise peptides presented by major histocompatibility complex (MHC) molecules. The peptide presented by MHC can be derived from the host proteins (self-peptides), pathogens (virus and bacteria), or tumours. The $\mathrm{T}$ cells need to differentiate between self and foreign peptides (including modify self), and are only activated upon MHC presentation of foreign epitopes. This recognition, driven by the TCR, is the critical first step of T cell activation preceding the immune response.

MHC molecules, also called human leukocyte antigens or HLA in humans, are extremely polymorphic, ensuring that a wide range of peptides can be presented to $\mathrm{T}$ cells. MHC molecules are divided into two main classes, i.e., I and II, and are restricted to either CD8+ or CD4+ T cells, respectively. In this review, we focus on the TCR recognition of peptide (p) presented by MHC class I (MHC-I) molecules only. The MHC-I antigen binding cleft is closed at the N-terminal and C-terminal regions (Figure 1A), while MHC-II molecules have an open-ended cleft. These differences between open and closed ends of the cleft changes the preferred length of the bound peptide, whereby MHC-I often binds shorter (8-10 residues) peptides than MHC-II (>11 residues), albeit with some exceptions [1]. MHC-I molecules have a series of pockets in the cleft, A to F, harbouring different chemical properties between different allomorphs resulting in the ability to bind different peptide repertoires. The B and F pockets are where the primary anchor residues, the second and last positions of the peptide (P2 and P $\Omega$, respectively), bind to the MHC-I (Figure 1B). These residues are often conserved between different peptides binding to the same MHC, for example, for peptides binding to HLA-B*35:01, a P2-Pro is often observed as well as $P \Omega-\operatorname{Tyr}[2,3]$. 


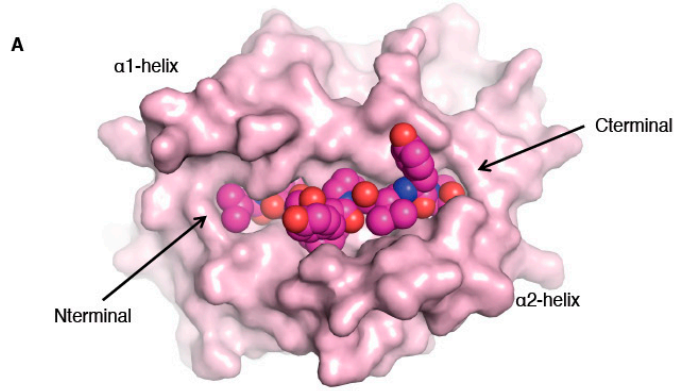

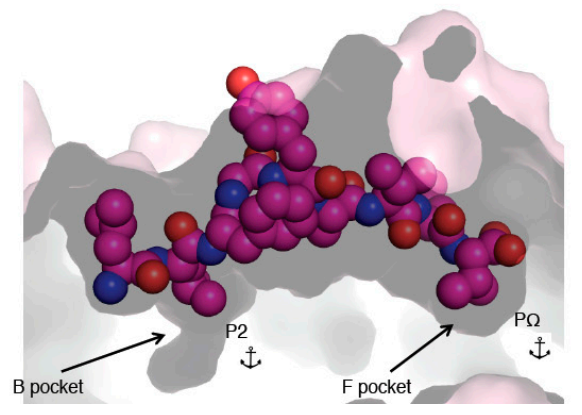

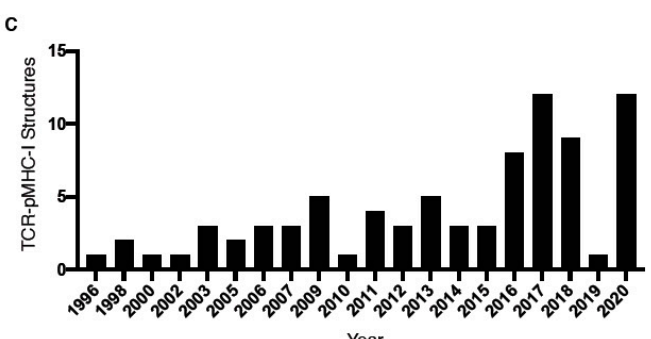

C

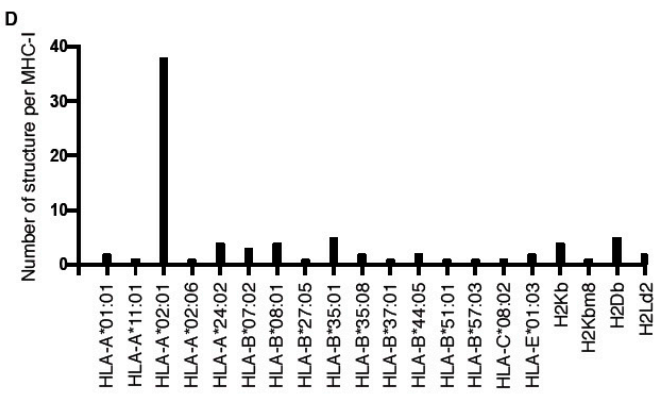

Figure 1. pMHC-I structure and current T cell receptor (TCR)-pMHC-I structures available. (A,B) Cleft of major histocompatibility complex (MHC)-I molecule (pale pink) represented as surface from a top-down view (A) and side view (B); the peptide is represented as pink spheres with the anchors residues at position 2 (P2) and at the last position (P $\Omega)$ in the B and F pockets (B). (C,D) Number of TCR-pMHC-I structures solved per year (C) or per MHC-I (D).

To recognise the highly polymorphic MHC and the large repertoire of peptides, TCRs also need to be extremely diverse. Diversity in the TCR repertoire is achieved through the random genetic rearrangement of Variable (V or TRV), Diversity (D), and Joining (J) gene segments for TCR $\beta$ chain (V and J for TCR $\alpha$ chain) [4]. TCRs possess three regions of variability, commonly known as the complementary determining regions (CDR1, CDR2, and CDR3), which make up the antigen-binding site that directly interacts with pMHC. The CDR1 and CDR2 regions are germline-encoded by the $V$ gene segment, whilst CDR3 hyper-variability is further accentuated through the addition or removal of nucleotides $(\mathrm{N})$ at $\mathrm{V}(\mathrm{D}) \mathrm{J}$ junctions [5]. Theoretically, the random rearrangement of TCR gene segments can give rise to a diversity of $10^{15}-10^{20} \mathrm{~T}$ cell clonotypes [6]; however, thymic selection events during T cell maturation trims this down to a TCR repertoire of $2.5 \times 10^{7}$ within an individual [7]. This provides enormous $\mathrm{T}$ cell diversity to recognise antigenic peptides presented by MHC molecules, making each TCR-pMHC complex structure unique in the recognition of pathogens by the adaptive immune system.

The first TCR-pMHC-I structure solved was by Garboczi and colleagues using X-ray crystallography in 1996 for HLA-A*02:01 presenting the Tax peptide from human T cell lymphotropic virus in complex with the A6 TCR (Table 1) [8]. Since then, 81 unique TCRpMHC-I complexes have been solved and are available in the Protein Data Bank (PDB; Table 1), with more than half of these complexes solved in the last 5 years (Figure 1C). Despite this increase in number over the last few years, those 81 TCR-pMHC-I complexes still represent a very narrow slice of the peptide repertoire. For example, thus far only 20 different MHC allomorphs have been crystallised in complex with a TCR (Figure 1D, Table 1). The addition of these recent structures allows us to observe how TCRs can recognise HLA-A*01:01 [9]; HLA-A*11:01 [10]; HLA-B*07:02 [11]; HLA-B*37:01 [12]; HLA$\mathrm{A}^{*} 02: 06$ [13]; and, for the first time, HLA-C [14].

Some of the most striking features revealed over the last few years include the first reversed docking MHC-I restricted TCR [15], how a TCR can flip the peptide upon binding [16], how $\delta \beta$ and $\gamma \delta$ TCRs recognise pMHC [17-19], and the revelation of new rules defining TCR cross-reactivity [20]. 


\section{TCR-pMHC-I Structures: Making Some Common Rules}

\subsection{Canonical TCR Docking}

Until 2016, all MHC-I-restricted TCRs adopted a conserved and canonical docking topology onto the pMHC-I complex (Figure 2A). The TCR $\alpha$ chain was atop the MHC-I $\alpha 2$-helix while the TCR $\beta$ chain was above the $\alpha 1$-helix of the MHC-I. A notable exception to this common docking mode was revealed in a mouse model of influenza infection (Figure 2B), and is described below (Section 3, [15]). With the exception of this mouse TCR, the other 80 unique complexes of TCR-pMHC-I all exhibit conserved canonical binding (Figure 2C).
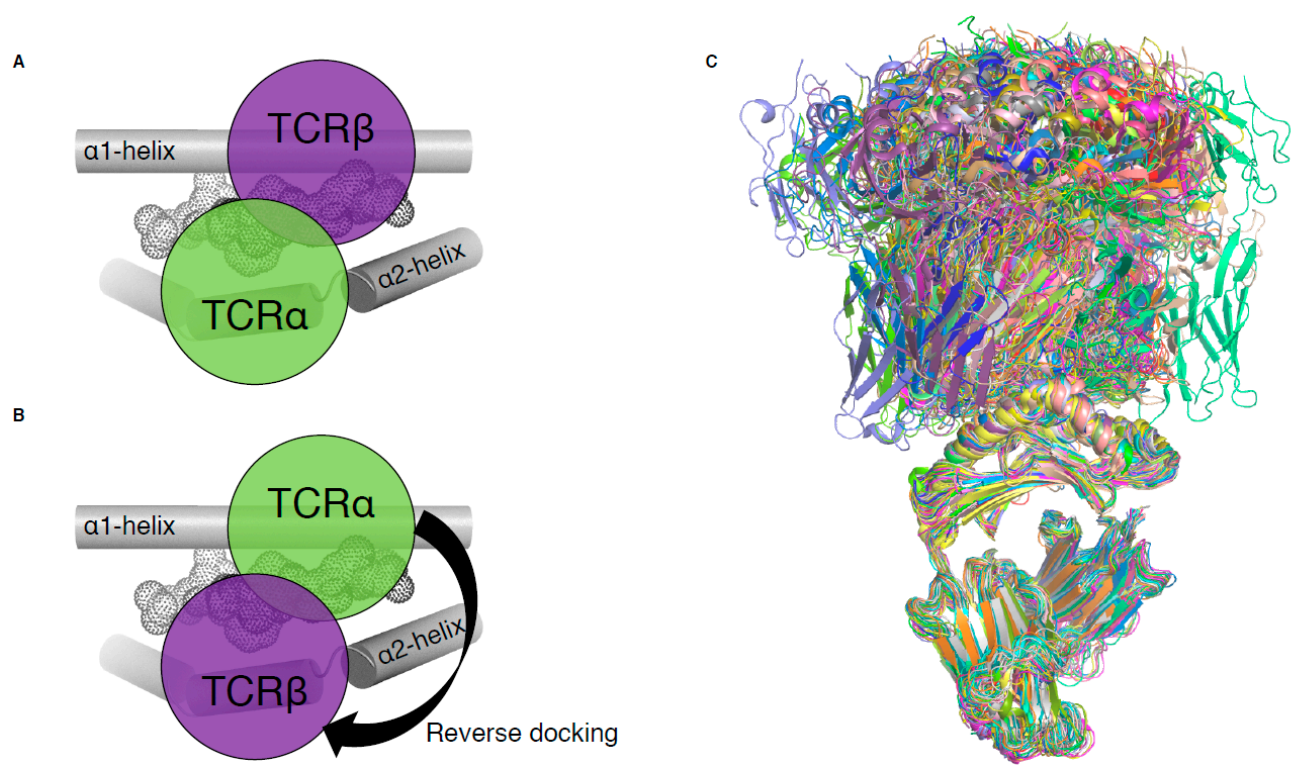

Figure 2. TCR docking on pMHC-I complex. (A) Schematic of canonical TCR docking on pMHC-I, whereby the TCR $\alpha$ (green) is above the MHC-I $\alpha 2$-helix (grey tube) and the TCR $\beta$ chain (purple) is above the MHC-I $\alpha 1$-helix (grey tube). (B) Schematic of reversed docking for TCR, with the arrow indicating a $180^{\circ}$ shift from the canonical docking mode (shown on (A)). Here, the TCR $\alpha$ (green) is above the $\alpha 1$-helix, while the TCR $\beta$ chain (purple) is above the $\alpha 2$-helix. The peptide is represented as dots on panels (A,B). (C) Overlay of all TCR-pMHC-I structures from Table 1, aligned on the MHC-I antigen binding cleft (residues 1-180).

\subsection{CDR Loops Role in Binding $p M H C$}

The canonical binding of TCR with pMHC complex has also led to the generalisation of the role of the CDR loops, due to their most frequent localisation. Thereby, it is generally accepted, and often observed, that the germline encoded CDR1 and CDR2 loops are mainly focused on the recognition of the MHC molecule itself, while the hypervariable CDR3 loops are the main drivers of peptide recognition. This observation suggests that there might be a co-evolution of TCR genes (CDR1/2 germline encoded loops) with MHC molecules [21,22].

\subsection{Co-Contribution of Both TCR Chains}

Despite the diversity of TCR docking angle and mode observed among those 81 structures (Figure 2C), co-contribution of both TCR chains is a recurring feature. The TCR $\alpha$ chain contributes between 28 and $78 \%$, with an average of $52 \%$, while the TCR $\beta$ chain contributes to $22-72 \%$, with an average of $48 \%$, to the pMHC interaction (Table 1). Half of the complexes fall within the $40-60 \%$ contribution between the two chains, showing a roughly shared and balanced contribution of both TCR chains. 


\subsection{Co-Binding of Peptide and $M H C$}

In addition to the co-contribution of both TCR chains, currently, all TCR-pMHC-I structures show that the TCR contacts both the peptide antigen and MHC. The peptide, despite its small size compared to the MHC molecule, can have a large contribution ranging from 12 to $49 \%$ of the pMHC buried surface area (BSA), with an average of $29 \%$ (Table 1). The contribution of the peptide antigen towards the pMHC-TCR interaction is a unique and shared feature among all peptide-specific T cells, for both MHC-I or MHC-II. This feature is not shared with lipid- or metabolite-derived specific TCRs for which the recognition of both MHC/MHC-like molecules and the bound antigen is not a requirement. For example, the structure of the autoreactive BK6 TCR, able to recognise multiple self-lipid antigens, solved in complex with the MHC-like molecule CD1a showed that the TCR could bind to CD1a without contacting the bound lipid [23]. This docking mechanism favours the recognition of multiple lipid antigens, decreasing TCR specificity that can in some cases lead to T cell autoimmunity. Other examples involve mucosal-associated invariant $\mathrm{T}$ cell (MAIT) specific for the MHC-like molecule, MR1. The MR1 molecule presents small metabolites deeply buried in the cleft that is not contacted by the MAIT TCR upon binding [24,25].

\section{5. "On the Top" Binding Mode}

Despite the large diversity of docking angles, the structures solved thus far show that there is a requirement for MHC-I restricted TCR to "sit" on the top of the cleft (Table 1). This conserved localisation of the TCR ensures that the peptide and the MHC-I helices are always contacted by the TCR. This is a specific feature of peptide-MHC-I recognition, for which thus far no exception has been observed (Figure 2C). Given that a larger number of TCR antigen structures have been solved with pMHC-I complexes, this conservation is remarkable. This "on the top" interaction is not a requirement for $\gamma \delta$ TCR specific for the MHC-like molecule, MR1. Indeed, the recent structure of the G7 $\gamma \delta$ TCR in complex with MR1 shows that TCR does not always need to contact the antigen-binding cleft, and that $\gamma \delta$ TCR can adopt an "on the side" binding mode [26]. Interestingly, binding "on the top", rather than sideways, is a common characteristic of $\alpha \beta$ TCRs thus far. This conserved feature might be underpinned by the requirement for $\mathrm{T}$ cells to engage with pMHC complexes to pass thymic selection. TCR binding on top of the cleft also ensures that the co-factor molecule (CD8 and CD4) can be productively engaged with the pMHC complex, which has implication for $\mathrm{T}$ cell signalling and activation, and in turn, dictating the immune response.

\section{The Recent TCR-pMHC-I Structures Are Rule Breakers}

From the first structures of TCR binding to PMHC-I, some general rules were drawn that were observed in subsequent TCR-pMHC structures. However, as we are learning more about TCR interaction with pMHC complex, with twice more structures solved in the last 5 years, some exceptions have started to emerge against those earlier established rules.

\subsection{Reverse Dockers}

In 2016, we identified the basis of mice influenza-specific TRBV17+ CD8+ T cells' poor recruitment from naïve to immune repertoire [15]. X-ray crystallography revealed that such $\mathrm{T}$ cells exhibit TCRs that recognised $\mathrm{pMHC}$ with a reversed-polarity docking topology (Figure 2B). Two of these TRBV17+ TCRs, NP1-B17 and NP2-B17, were observed to dock onto pMHC-I with $180^{\circ}$ reversed polarity, where the TCR $\alpha$ chain is docked over the $\alpha 1$-helix and the TCR $\beta$ chain is contacting the $\alpha 2$-helix (Figure 2B). Interestingly, these TCRs were able to bind to pMHC-I with moderate affinities $\left(K_{d}\right.$ of 30-40 $\left.\mu \mathrm{M}\right)$ relative to the range in other TCR-pMHC-I (Table 1); however, they were poorly activated upon pMHC-I recognition. This highlights that TCR-pMHC-I affinity is not the sole determinant behind T cell activation. The reversed docking topology could limit or impair CD8 co-factor binding, and the consequences for a lack of mediated downstream effects that lead to poor $\mathrm{T}$ cell activation. Additionally, the existence of a reversed-polarity docking TCR, poorly recruited 
into the immune repertoire, favours the selection model theory $[27,28]$ in which MHC restriction may not be an intrinsic feature of TCRs through co-evolution (germline-encoded model [21,22]), but instead due to the regulatory processes within thymic selection. This suggests that the canonical docking topology observed for all $\alpha \beta$ TCRs derived from the immune pool might be a direct requirement of $\mathrm{T}$ cell activation.

\subsection{CDR3 Loops Do Not Always "See" the Peptide}

In addition to binding in a reversed orientation, the NP1-B17 and NP2-B17 TCRs docked with their TCR $\alpha$ chain shifted towards the C-terminus of the pMHC-I and perched higher than the $\alpha 1$-helix, with the CDR3 $\alpha$ loop interacting with residues (MHC residues 18 and 89) outside the antigen-binding cleft (Figure 3A) [15]. The shifted TCR $\alpha$ chain only contacted the MHC molecule, and not the peptide at all. In addition, the reverse docking topology placed the TCR $\beta$ chain above the peptide, where the CDR2 $\beta$ loop and framework (FW) residues from the $\beta$-chain interacted directly with the bound peptide (Figure 3B). The CDR3 $\beta$, on the other hand, formed interactions with residues within the $\alpha 1$-helix and not the peptide. Surprisingly, this meant that peptide interaction was solely mediated by the germline encoded CDR2 $\beta$ and FW $\beta$, which forms the basis of TRBV17 gene usage.

A

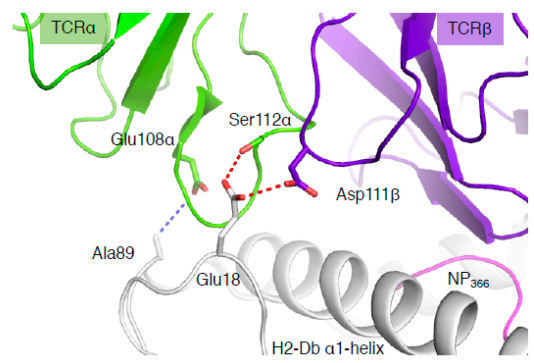

B

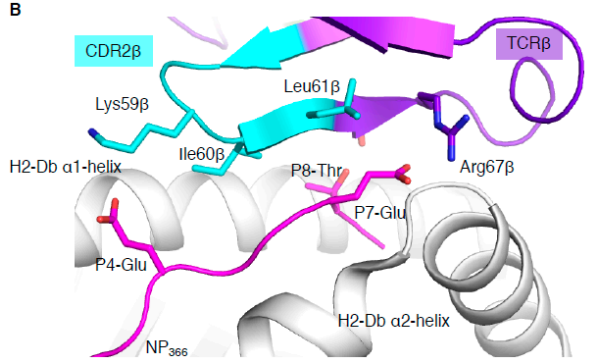

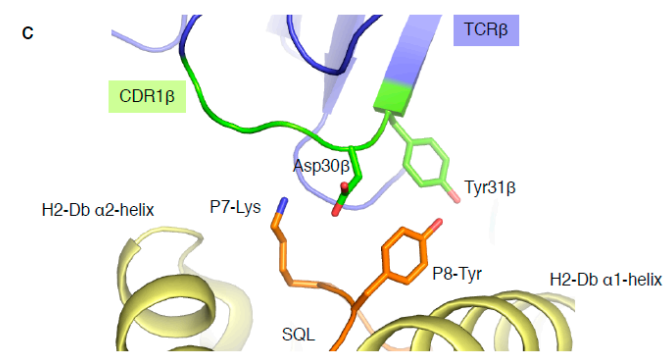

D

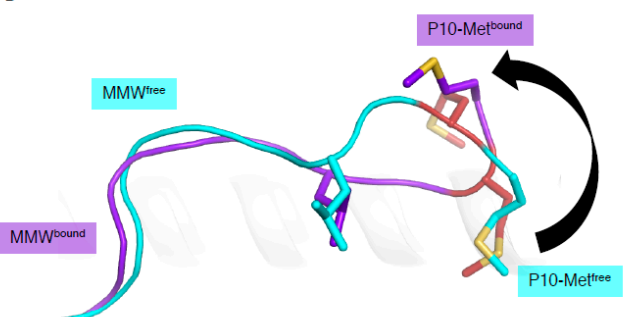

Figure 3. Unconventional TCR docking or TCR-peptide interactions. (A) NP2-B17 TCR ( $\alpha$ in green and $\beta$ in purple) contacting the loops outside the H-2D $\mathrm{D}^{\mathrm{b}}$ antigen-binding cleft, and, namely, the residues 18 and 89 (white stick). The red and blue dashed lines represent the hydrogen and Van der Waals interactions. (B) The NP2-B17 TCR CDR2 $\beta$ (cyan) and framework $\beta$ (purple) interact with the $\mathrm{NP}_{366}$ peptide (pink) presented by $\mathrm{H}-2 \mathrm{D}^{\mathrm{b}}$ (white). (C) TRBV13-3+ TCR ( $\beta$ chain in blue) with the CDR1 $\beta$ (green) residues (sticks) interacting specifically with the malaria-derived SQL peptide (orange) P7-Lys and P8-Tyr (sticks) presented by the H-2D ${ }^{b}$ (yellow). (D) Comparison of the MMW peptide structure (loop) presented by human leukocyte antigen (HLA)-A*02:01 without (cyan) or with the DMF5 TCR (purple). The DMF5 TCR binding leads to a register shift of the MMW peptide, whereby the P10-Met ${ }^{\text {free }}$ in the HLA cleft (cyan sticks) is flipped out of the cleft (P10-Met ${ }^{\text {bou }}$ nd in purple stick) upon binding of the DMF5 TCR.

\subsection{When the Peptide Drives the Show}

In most TCR-pMHC-I structures, the CDR1/2 loop has a larger role in contacting the $\mathrm{MHC}$ than the peptide. These recurrent observations lead to the theory that the germlineencoded regions of TCRs might have co-evolved to recognise MHC molecules [22]. This is aligned with the fact that the hypervariable non-germline encoded CDR3 loops are most often seen to dominate the interaction with the peptide. However, some exceptions have emerged, whereby bias usage of specific germline TRBV genes were driven by direct interaction with the peptide [10,29]. The first example in mouse [29] shows an 
almost exclusive use of $\mathrm{V} \beta 8.1$ gene (TRBV13-3) to recognise the malaria-derived SQL peptide presented by $\mathrm{H}-2 \mathrm{D}^{\mathrm{b}}$. The structure of a TRBV13-3+ TCR in complex with $\mathrm{H}-$ $2 D^{b}$-SQL revealed that the CDR1 $\beta$ loop motif ${ }^{30} \mathrm{DY}^{31}$ was interacting with the peptide. The Asp30 $\beta$ only contacted the peptide while the Tyr31 $\beta$ contacted both the peptide and $\mathrm{H}-2 \mathrm{D}^{\mathrm{b}}$ molecule (Figure $3 \mathrm{C}$ ). The ${ }^{30} \mathrm{DY}^{31}$ motif is unique to TRBV13-3 within the mouse TRBV. Mutagenesis studies demonstrated the critical role of the ${ }^{30} \mathrm{DY}^{31}$ motif in binding to peptide residues P7-Lys and P8-Tyr, showing that the TRBV13-3 bias gene usage was driven by the SQL peptide itself [29]. A second example was based on the discovery of a TRBV bias in Dengue-specific T cells [10]. We showed that TRBV11-2 was largely used in T cells and was able to recognise the $\mathrm{NS}_{133}$ peptide presented by HLA-A*11:01 when the peptide was derived from three different Dengue serotypes (DENV1, DENV3, and DENV4, (GTSGSPI $/$ VNR)). However, if the $\mathrm{NS}_{133}$ peptide was derived from DENV2 serotype (GTSGSPIDK), the TRBV11-2 gene was avoided in the T cell repertoire. Structural analysis of a TRBV11-2+ TCR, D30 TCR, in complex with HLA-A*11:01 presenting the DENV1 and DENV3/4 derived peptides showed direct interaction between the germline-encoded CDR2 $\beta$ loop and the NS3 ${ }_{133}$ peptides. Mutagenesis analysis showed the importance of the TCR-peptide interaction (Asn58 $\beta$ with P9-Asn). In addition, TCR sequence analysis revealed a shared CDR2 $\beta$ loop motif with other TRBVs able to recognise the same Dengue serotype [10].

These studies show that the peptide can be a key driver of TCR bias that is selective for specific CDR1/2 residues, which interacts directly with the peptide antigen independent of MHC restriction.

\subsection{Does Length Really Matter?}

MHC-I molecules usually present short peptides of 8 to 10 residues in length. However, advances in mass spectrometry and peptide elution analysis has revealed that longer peptides ( $>10$ residues) could be presented by MHC-I molecules [1]. Despite this, it is unclear if a TCR is able to engage with peptides of multiple lengths or whether there is a length restriction. A study by Ekeruche-Makinde and colleagues showed that peptide length is linked with TCR engagement outcome [30]. Using a combinatorial peptide library with varied length, they showed that TCR cross-reactivity was dependent on the length of the presented peptide, and that TCRs were unable to react to peptides with different lengths [30]. Therefore, the observation from Riley and colleagues defining the basis for the DMF5 TCR cross-reactivity was surprising [16]. The DMF5 TCR is able to recognise a 10mer MART-1 epitope (ELA), can cross-react onto a 10mer SML peptide by a conserved docking mode, and is also able to cross-react with a 10mer MMW peptide presented by HLA-A*02:01 molecule. The MMW peptide is presented in a canonical fashion by HLA molecules, whereby the peptide is primarily anchored by its P2-Met and P10-Met (P $\Omega$ ). Upon DMF5 TCR binding, the 10mer peptide is "flipped out" of the C-terminal region (Figure 3D), where P10-Met is pushed out of the cleft, and P9-Met becomes the primary anchor [31]. This change of conformation causes the MMW peptide to adopt a 9mer conformation in the cleft after DMF5 TCR binding. The study also showed that the MDF5 TCR could recognise a 9mer truncated version of the MMW, but not a 10mer MMW peptide with a P10-Val mutation [16]. The Val is a more favoured $P \Omega$ anchor for HLA-A*02:01 molecule and might prevent the structural change required for DMF5 TCR recognition of the 10mer MMW peptide. Altogether, this shows that the DMF5 TCR is able to engage with the 9 mer peptide, even when presented with a 10mer peptide, and can recognise different peptide lengths, dramatically increasing its peptide repertoire.

\section{The Scarlet pMHC: Multiple TCRs Recognising the Same pMHC-I}

It is uncertain as to whether having multiple TCRs engaging the same pMHC complex is considered to be advantageous or detrimental for an effective functional adaptive immune response in an individual. At the population level, there is an advantage of having multiple TCRs able to engage with the same peptide, as this would provide different 
TCR-peptide interactions that could limit viral escape. There are a number of examples of multiple TCRs recognising the same pMHC-I (Table 1). This gives an opportunity to identify common or divergent structural features between TCRs engaging the same pMHC-I.

\subsection{Conserved Peptide Interactions}

The human cytomegalovirus (CMV)-derived NLV peptide (NLVPMVATV) is presented by HLA-A*02:01 in a canonical fashion with solvent-exposed P4-Pro, P5-Met, and P8-Thr and potential TCR interaction [32]. To date, the structures of three TCRs (RA14, C7, C25) in complex with HLA-A*02:01-NLV are available [32,33]. The TCRs dock onto HLA-A ${ }^{*} 02: 01-\mathrm{NLV}$ with different angles $\left(35^{\circ}, 29^{\circ}\right.$, and $\left.61^{\circ}\right)$, but all docking modes bury $85-90 \%$ of the peptide solvent accessible surface $[32,33]$. All three TCRs contact the peptide in the same way, with the CDR $1 \alpha$ and CDR3 $\alpha$ loops interacting with the $\mathrm{N}$-terminal part of the peptide, and the CDR3 $\beta$ loop contacting the C-terminal part of the peptide with the CDR1 $\beta$ loop contributing to these interactions for the RA14 TCR [32,33]. Interestingly, despite the additional contribution of the CDR1 $\beta$, RA14 TCR has the lowest binding affinity to HLA-A*02:01-NLV when compared to C7 and C25 (Table 1). While all the TCRs interact with the peptide in a similar fashion, each uses different strategies to engage the HLA-A*02:01, which could be due to their different TCR gene usages and might underpin the different affinities observed.

\subsection{Peg Notch or Peg Not?}

The immunodominant influenza-derived M1 peptide (GILGFVFTL) presented by HLA-A*02:01 is featureless, lying flat within the HLA cleft, and has been described as "vanilla" because of this lacklustre trait [34]. Due to the lack of prominent features of this epitope, M1-specific TCRs are extremely biased with the expression of TRAV27/TRBV19 combinations [34], and the preferential selection of an RS motif within the CDR3 $\beta$ loop. The structure of a prototypical TRAV27/TRBV19 TCR expressed in unrelated individuals (public TCR), JM22, in complex with HLA-A*02:01-M1, showcased the first description of a shape complementarity feature described as a "peg" and "notch" interaction [34]. This interaction portrays a gap between P5-Phe and P7-Phe of the peptide, and the HLA $\alpha 2$-helix (Gln155 and Ala150) forms a "notch", with the conserved Arg98 of the CDR3 $\beta$ forming the "peg" docks into the notch, which was found to also be able to form a network of hydrogen bonds (Figure 4A).

In addition, three more TCR-HLA-A*02:01-M1 structures have been solved (Table 1), two with TRBV19+ TCRs and one with a TRBV27+ TCR, none of them sharing the ${ }^{98} \mathrm{RS}^{99}$ motif in their CDR3 $\beta$ loop. LS01 TCR (TRAV24/TRBV17) has a Phe instead of the Arg in its CDR3 $\beta$ loop (Figure 4B), which acts as the peg to form a peg-notch interaction but lacks the hydrogen bond network observed with the JM22 TCR [35]. The resulting affinity of LS01 is therefore five times lower than that of JM22 (Table 1) [35]. The LS10 TCR (TRAV38-2/DV8*01/TRBV19) structure with HLA-A*02:01-M1 shows that the P5Phe of the peptide adopted a different conformation away from the HLA $\alpha 2$-helix due to interaction with the CDR3 $\alpha$ loop. Due to the peptide structural changes, the side chain of P5-Phe fills the "notch" and instead forms a small hydrophobic pocket that interacts with the CDR3 $\alpha$ loop (Ala98 and Gly99; Figure 4C). Despite the loss of the peg-notch interaction, the LS10 TCR still maintains an affinity similar to LS01 TCR [35], but lower than the JM22 TCR (Table 1). The F50 TCR (TRAV13-1/TRBV27) utilises a large Trp99 $\beta$ within its CDR3 $\beta$ loop to occupy the notch and contacts the HLA (Ala150, Val152, and Gln155; Figure 4D). Despite conserving a peg-notch interaction, the affinity of the F50 TCR for HLA-A*02:01-M1 is considerably lower than the other TCRs $\left(\mathrm{K}_{\mathrm{d}}\right.$ of $\left.76 \mu \mathrm{M}\right)$ [36]. The F50 TCR interacts differently with HLA-A*02:01-M1 than JM22 TCR, and makes less contact with the peptide than JM22 TCR [36]. Altogether, this shows that the CDR3 $\beta$ loop conserved Arg98, has an important contribution to the hydrogen network, and is the best molecular solution to interact with the "vanilla" HLA-A*02:01-M1 complex. 

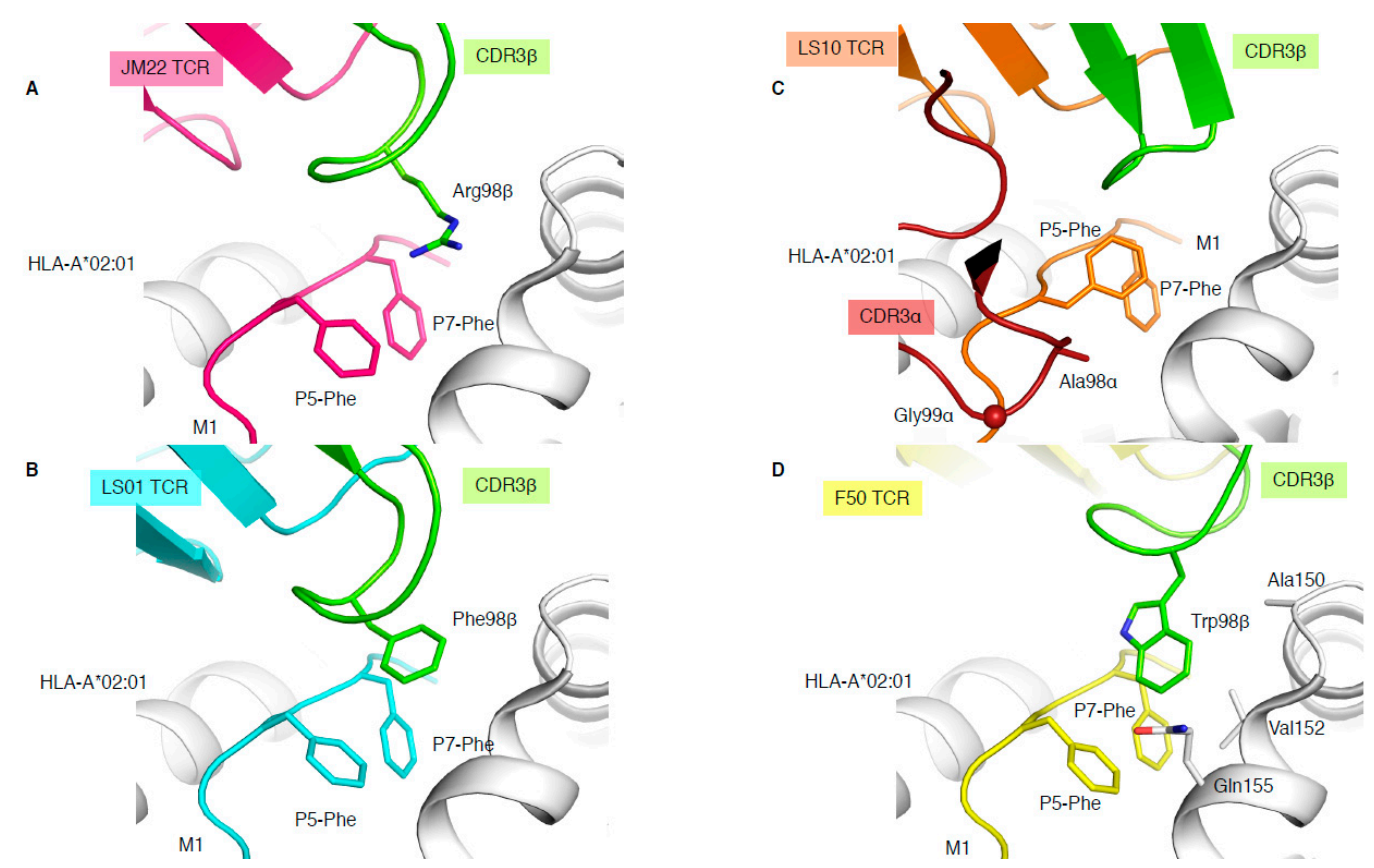

Figure 4. Different solutions to engage with the same pMHC-I complex. Structures of HLA-A*02:01 (white) presenting the M1 peptide in complex with the JM22 TCR (A), LS01 TCR (B), LS10 TCR (C), or F50 TCR (D). The structures were superimposed by aligning the cleft (residues 1-180) and presented in the same orientation. The M1 peptide is coloured as per the bound TCR in pink with JM22 (A), cyan with LS01 (B), orange with LS10 (C), and yellow with F50 (D), and the P5-Phe and P7-Phe are represented as sticks. The CDR3 $\beta$ loop is coloured in green for all TCRs, and the CDR3 $\alpha$ is removed from all panels but (C), where its coloured in red. The sphere on panel (C) represents the C $\alpha$ atom of the F50 TCR Gly99 $\alpha$.

\subsection{Crushing the Peptide: Binding at All Costs}

Most of the tumour-derived CD8+ T cell epitopes for which we have structural information are derived from the NY-ESO-1 (New York esophageal squamous cell carcinoma 1) cancer/testis antigen expressed in a range of cancers, and therefore are a great target for immunotherapeutic design [37,38]. A large amount of work has been done on HLA-A*02:01-restricted epitopes (Table 1), but a recent study focused on the NY-ESO-1 epitope restricted to the HLA-B*07:02 molecule [11]. The study shows that a 13mer peptide, NY-ESO-1-60-72 presented by HLA-B*07:02, was able to activate CD8+ T cells (IFN $\gamma$ production), and in addition described the first structure of a TCR engaging with an HLA-B*07:02 molecule. The structures of two TCRs (KFJ37 and KFJ5) in complex with the HLA-B*07:02NY-ESO-1-60-72 complex showed very different interactions with the pHLA, despite a similar docking angle $\left(70^{\circ}\right)$. Even more striking, the peptide itself was in a completely different conformation when bound to the two TCRs, suggesting that the NY-ESO-1-60-72 peptide conformation was flexible in the cleft of HLA-B*07:02. The KFJ37 TCR stabilised the bulged conformation of the peptide, whilst the KFJ5 TCR pushed the peptide down toward the cleft. As a result, the NY-ESO-1-60-72 peptide adopted a constrained and helical conformation upon binding of the KFJ5 TCR. This dramatic conformational change of the peptide could explain the fivefold difference in affinity between the KFJ5 (Kd > $200 \mu \mathrm{M})$ and $\mathrm{KFJ} 37(\mathrm{Kd} \approx 40 \mu \mathrm{M}) \mathrm{TCRs}$.

Altogether, this shows that multiple TCRs can engage with the same epitope, via conserved or mimicked interaction, or by an alternate mode of recognition. In each case, the peptide or the TCR structural plasticity may play a role in structural rearrangement, despite a cost on the overall affinity.

\section{T Cell Cross-Reactivity: Self-Defence to Self-Sabotage}

$\mathrm{T}$ cell cross-reactivity is the recognition of at least two unique $\mathrm{pMHC}$ complexes by the same TCR, resulting in T cell activation. As there are infinite possibilities of foreign peptides 
that need to be recognised by a finite number of TCRs within the T cell repertoire, $\mathrm{T}$ cells must cross-react to achieve a high level of protection [39]. T cells are like funambulists, walking a fine line between recognising a wide range of foreign peptides while not "falling" and be activated by a self-peptide. The availability of increased TCR-pMHC-I structures brings forth the emergence of mechanisms underpinning $\mathrm{T}$ cell cross-reactivity.

\subsection{Molecular Mimicry Leads to a Million Peptides Recognised and Could Prime Autoimmunity}

It is known that when the balance of TCR recognition and reactivity is disrupted, complications such as autoimmunity can arise [40]. The 1E6 T cell clone isolated from a type I diabetic patient recognised the preproinsulin (PPI) signal peptide presented by HLA$\mathrm{A}^{*} 02: 01$ [41]. The 1E6 $\mathrm{T}$ cell clone was able to recognise 1 million different peptides bound to the HLA-A*02:01 molecule, and the structure of 1E6 TCR in complex with some of those peptides revealed the basis of this multi-ligand recognition [20]. The seven structures with 1E6 TCR complex to HLA-A*02:01 presenting altered PPI ligands showed similarities of recognition mode. This was driven by a conserved ${ }^{4} \mathrm{GPD}^{6}$ motif in the peptide interacting with an aromatic cap formed by the TCR CDR3 loops (Tyr97 $\alpha$ and Trp97 $\beta$ ) (Figure 5A). This illustrates the ability of molecular mimicry to facilitate $\mathrm{T}$ cell cross-reactivity through conserved peptide motif. Interestingly, some of the altered PPI peptides were from a pathogenic source, for which the 1E6 TCR possessed higher affinity, such as the RQF peptide $\left(\mathrm{K}_{\mathrm{d}}\right.$ of $\left.0.5 \mu \mathrm{M}\right)$ from C. asparagiforme, than for the PPI peptide $\left(\mathrm{K}_{\mathrm{d}}>200 \mu \mathrm{M}\right)$ [20]. This suggests that pathogen-derived peptides could prime the 1E6 T cell clone and might be responsible for the onset of type I diabetes.
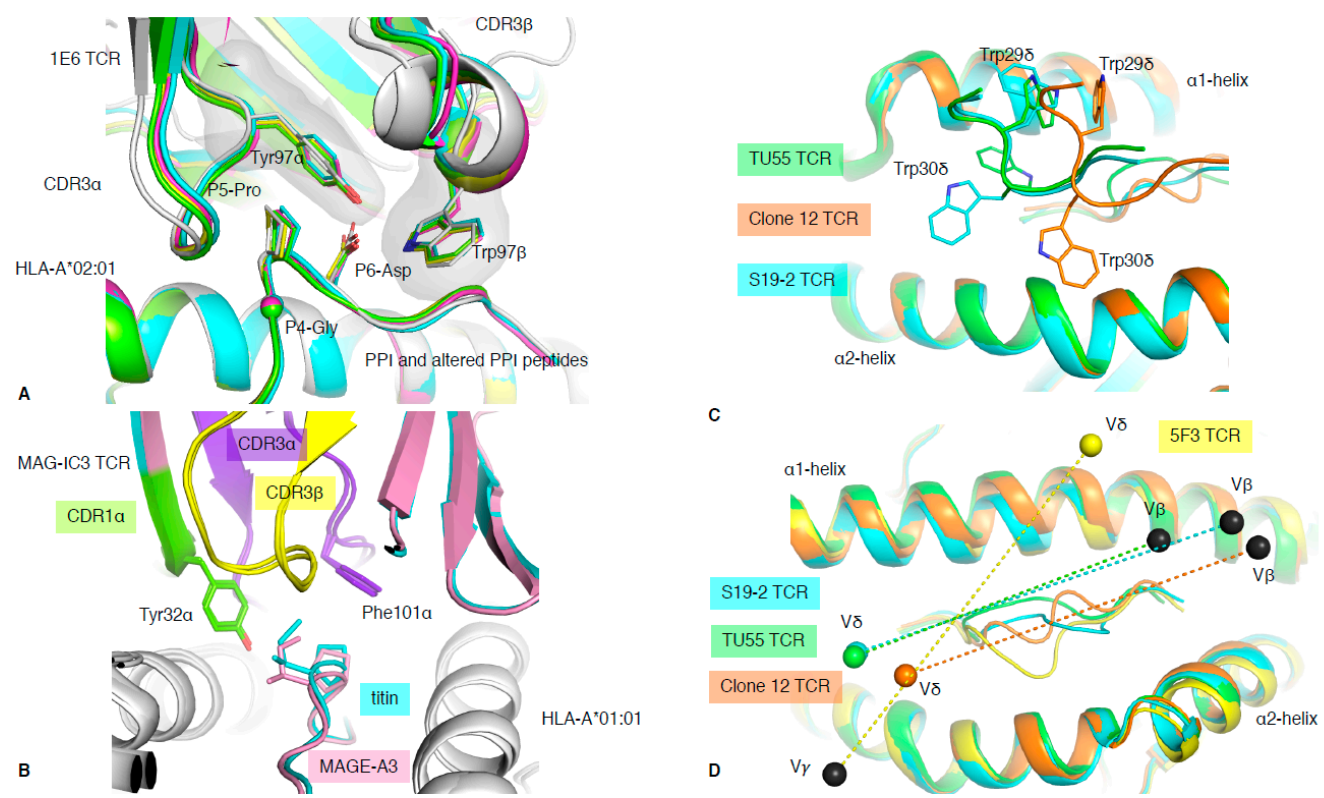

Figure 5. TCR cross-reactivity and non- $\alpha \beta$ TCR recognition. (A) Structural overlay of the 1E6 TCR in complex with the PPI (white) and altered PPI peptides: YQF (green), RQW (orange), MVW (cyan), RQF-I (pink), and RQF-A (yellow). The conserved ${ }^{4} \mathrm{GPD}^{6}$ motif in the peptide is represented as sticks and spheres for the C $\alpha$ atom of the P4-Gly. The CDR3 loop residue Tyr97 $\alpha$ and Trp97 $\beta$ forming the hydrophobic cap are represented as sticks. (B) Structural overlay of the MAG-IC3 TCR in complex with the HLA-A*01:01 (white) presenting the MAGE-A3 (pink) or titin (cyan) peptide. The TCR is coloured as per the bound peptide, with the CDR1 $\alpha$ in green, CDR3 $\alpha$ in purple, and CDR3 $\beta$ in yellow. (C) Top view of structural overlay of $\delta \beta$ TCRs in complex with pHLA-I complex. The TU55 TCR-HLA-B*35:01-IPL is in green, S19-2 TCR-HLA-A24:02-RYP is in cyan, and clone 12 TCR-HLA-B*35:01-IPS is in orange. The conserved TRDV1*01 CDR1 is

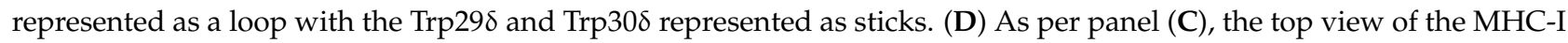
cleft with a structural overlay of three $\delta \beta$ TCRs-pMHC-I complex and the 5F3 $\gamma \delta$ TCR added (yellow). The mass centres for the $\mathrm{V} \beta$ or $\mathrm{V} \gamma$ are represented as black spheres, while the $\mathrm{V} \delta$ mass centres are presented as coloured spheres matching each TCR as per panels (C,D). All the structural overlays are aligned on the MHC-I cleft (residues 1-180). 


\subsection{Molecular Mimicry Leads to Off-Target Toxicity}

TCRs recognise the composite surface formed by the peptide and MHC molecule. Shared conformation between MHC molecules, and peptides, can lead to two distinct pMHC complexes having a similar surface conformation. As such, two pMHC complexes (for e.g., foreign and self-peptides) can look alike and can no longer be distinguished as being different by TCRs. This results in abnormal TCR recognition due to molecular mimicry. TCRs have a low affinity for foreign peptides ( $\mu \mathrm{M}$ range), and are even weaker for self-peptide due to thymic selection. While this is necessary to avoid $\mathrm{T}$ cells being activated by healthy cells and causing autoimmunity, in the case of cancer, it does lead to an overall poor T cell response. Typically, TCR affinity towards tumour-associated antigens (TAA) is lower than for pathogenic antigens. One way to improve $\mathrm{T}$ cell reactivity towards tumours is to engineer high-affinity TCRs to be used in T cell immunotherapy [9]. However, the fine balance limiting autoimmunity can be disrupted by excessively high TCR affinity. The study on MAGE-A3 epitope (TAA expressed in multiple cancer types) is an example of one such adverse reaction. A TCR recognising the MAGE-A3 peptide was a candidate for the enhanced affinity TCR approach. This modified TCR, called MAG-IC3 TCR, exhibited very high affinity (nM range) for the HLA-A*01:01-MAGE-A3 complex (Table 1). Unfortunately, the MAGE-A3 peptide (EVDPIGHLY) shared five out of nine identical residues with another self-peptide (ESDPIVAQY) derived from the Titin protein on cardiac tissue. Molecular mimicry between the two peptides provoked fatal cardiac toxicity in two patients when treated with the MAG-IC3 enhanced affinity TCR, able to bind the two peptides due to cross-reactivity [42]. The structural comparison of the MAG-IC3 TCR in complex with HLA-A*01:01 presenting either MAGE-A3 or Titin -derived peptide confirmed that MAG-IC3 TCR bound similarly onto both pHLA due to molecular mimicry (Figure 5B). Although the MAG-IC3 TCR had a 10-fold lower affinity for the Titin-derived peptide than the MAGE-A3 peptide (Table 1), the high level of Titin expression in cardiac tissue increased the overall reactivity of the engineered $\mathrm{T}$ cell. The lower affinity for Titin might be due to a missing interaction between the TCR and the peptide at P5, where the MAGE-A3 peptide possesses an exposed P5-His, whilst the Titin peptide has a buried P5-Ala. Nevertheless, this illustrates that many factors, and not just affinity, can underlie cross-reactivity, which must be considered when engineering enhanced affinity TCRs.

\subsection{Cross-Reactivity Becomes Allo-Reactivity: Risk for Transplant Rejection}

Prior to organ or tissue transplantation, a close HLA match is sought out; however, a perfect match is near impossible due to the high level of polymorphism of HLAs. After transplantation, the host's T cells can recognise the donor's HLA molecule (allo-HLA) as foreign and become activated [43]. Allo-reactivity involves the recognition of both selfand a foreign-peptide in the context of different HLA molecules. There are very few examples where both self- and foreign-derived peptides are known. The most comprehensive example in human is the study of the allo-reactive LC13 TCR [44]. LC13 TCR is specific for HLA-B*08:01 presenting an Epstein-Barr virus (EBV) peptide called FLR [45]. This TCR is shared in HLA-B*08:01/EBV+ individuals (public TCR) and deleted in HLA-B*44:02/03+ individuals due to allo-reactivity with those HLA molecules. The allo-peptide was identified, and structural analysis showed that molecular mimicry was responsible for LC13 TCR allo-reactivity in a peptide-centric manner [44].

Recently, Wang and colleagues showed that $\mathrm{T}$ cell allo-reactivity can be specific for both the peptide and MHC molecule simultaneously [46]. The 1406 TCR was isolated from a hepatitis $\mathrm{C}$ virus (HCV)-positive/HLA-A ${ }^{*} 02$ :01-negative patient who received an HLA-A*02:01-positive liver transplant. The 1406 TCR was shown to be specific for the NS3 derived peptide (KLV) from HCV (Table 1). The 1406 TCR structure in complex with HLA$\mathrm{A}^{*} 02: 01-\mathrm{KLV}$ showed specificity towards the P1-Lys of the peptide (through electrostatic interaction). Interestingly, the structure of the HLA-A*02:01-KLV was similar to the one of HLA-A*02:01-MART-1. The major difference between the two peptides that could impact on 1406 TCR recognition was the critical P1-Lys, which is replaced by a P1-Glu (opposite 
charge) in the MART-1 peptide. Wang and colleagues mutated the MART-1 at P1 to obtain the MART-1-P1-Lys and tested the ability of 1406 TCR to bind to this modified MART-1 peptide. The SPR analysis revealed that while the 1406 TCR was not able to bind with the MART-1 peptide, it could bind the MART-1-P1-Lys but with lower affinity than the HCV-derived peptide. In this case, both the peptide and HLA molecules were critical for TCR recognition.

Thus far, the molecular basis of TCR allo-reactivity seems to follow the same principles as the one leading to the recognition of viral or pathogenic peptides [47].

There are still aspects of cross-reactivity that we do not understand. T cell crossreactivity encompasses "the good, the bad, and the ugly" of T cell activation. While it is clearly required that $\mathrm{T}$ cells are able to recognise multiple $\mathrm{pMHC}$ complexes for an effective immune response, this can also lead to disastrous outcomes. T cell cross-reactivity helps to limit the number of viral escapes due to mutations (the good [12,48]), can underpin autoimmune disease by priming of $\mathrm{T}$ cell (the bad [20]), and can even lead to self-destruction such as transplant rejection (the ugly [9]). By understanding such reactivity, we may in the future be able to halt, diminish, or prevent the negative effects of TCR cross-reactivity.

\section{Beyond $\alpha \beta$ TCR: $\delta \beta$ and $\gamma \delta$ TCRs Join the Party}

It is fairly common to link pMHC-I to $\alpha \beta$ TCR recognition; however, recent studies have shown that pMHC-I recognition is not limited to only $\alpha \beta$ TCRs. Indeed, we now know how $\mathrm{V} \delta$ segments can pair with $\mathrm{J} \alpha$ to form a $\delta \alpha$ chimeric TCR chain that can be paired with a TCR $\beta$ chain. The resulting TCR called either $\delta \alpha / \beta$ or $\delta \beta$ TCR can recognise peptides presented by MHC-I as well as lipids bound by MHC-like molecules [17]. In addition, there is an expansion of our knowledge on $\gamma \delta$ T cells from recognising empty MHC-like molecule such as T22 [49], to engaging directly with lipid-derived antigens [50,51], and binding pMHC-I complex [19]. It is likely that more information will emerge on the role and antigen repertoire of $\gamma \delta$ T cells in the coming years [26,52-54].

\subsection{Chimeric $\delta \beta$ TCR Recognition of $p M H C-I$ Complex}

In 2014 , the first structure of a chimeric $\delta \beta$ TCR, named clone 12 TCR, in complex with HLA-B*35:01 presenting the CMV derived IPS peptide was solved, alongside a $\delta \beta$ TCR-lipid-CD1d complex [17]. The clone 12 TCR was composed of a TRDV1*01 gene rearranged with the TRAJ52 to form the $\delta \alpha$ chain and paired with TRBV5-1*01 gene. The particularity of the TRDV1*01 gene is its unusual use of Trp residues in the CDR1 $\delta$ loop (TSWWSYY). Trp is a rare residue in proteins, encoded by a single codon (TGG); is the largest aromatic residue; and is not found in any CDR1 or CDR2 loops in TRAV, TRBV, TRDV, and TRGV other than the TRDV $1 * 01$ gene. Interestingly, the four structures of $\delta \beta$ or $\gamma \delta$ solved to date in complex with peptide-HLA all share the TRDV1*01 gene (Table 1, [17-19]). The clone 12 TCR docks onto HLA-B*35:01-IPS, similarly to a canonical $\alpha \beta$ TCR, where the $\delta \alpha$ chimeric TCR chain interacts with the $\alpha 2$-helix, with the $\beta$ chain above the $\alpha 1$-helix [17]. Interestingly, the two Trp residues from CDR1 $\delta$ contact both $\alpha 1$ and $\alpha 2$-helices, dominating the overall interaction for the pHLA complex $(27 \%$ of TCR BSA; Figure 5C). Subsequently, two more $\delta \beta$ TCR structures have been solved in complex with HIV-derived peptide HLAs (Table 1) [18]. The TU55 TCR is restricted to HLA-B*35:01 while the S19-2 TCR is restricted to HLA-A*24:02. Despite recognising different pHLAs and using different TRBV genes (Table 1), their CDR1 $\delta$ binds similarly over the pHLA complex, but differently to clone12 TCR (Figure 5C). Therefore, there is some flexibility in how the $\delta$ chain can bind and recognise pHLA complexes.

\section{2. $\gamma \delta$ TCR Recognition of Peptide Antigen Presented by MHC}

It has been long thought that $\gamma \delta \mathrm{T}$ cells, in contrast to $\alpha \beta$ T cells, can recognise $\mathrm{MHC}$ or MHC-like molecules without the requirement to contact or to even enclose an antigen bound in the cleft [55]. This was demonstrated with the early structures of $\gamma \delta$ TCRs solved with MHC-like molecule such as T22 [49]. Even more recently, the structure of a $\gamma \delta$ TCR in 
complex with MHC-like molecule MR1 shows that $\gamma \delta$ TCRs are not constrained to bind atop the antigen-binding cleft [26], clearly avoiding any bound metabolite-derived antigen. Interestingly, in 2018, Benveniste and colleagues solved the first $\gamma \delta$ TCR-peptide-HLA structure [19], and the only one to date. The 5F3 $\gamma \delta$ TCR is composed of a TRDV1*01 and TRGV8*01 TCR genes, and therefore shares the TRDV1*01 usage with the previously solved $\delta \beta$ TCRs mentioned above. The surprising feature of this 5F3 $\gamma \delta$ TCR recognition of pHLA complex resides in its orientation or docking topology. Indeed, while the $\delta \beta$ TCRs docked similarly to $\alpha \beta$ TCRs, whereby the $\mathrm{V} \alpha$ or $\mathrm{V} \delta$ domains are over the HLA $\alpha 2$-helix, the 5F3 $\gamma \delta$ TCR docked in the opposite orientation or reversed as per discussed in Section 3 (Figure 2B). The 5F3 V $\delta$ domain is docked above the HLA $\alpha 1$-helix, while the $\mathrm{V} \gamma$ is above the HLA $\alpha 2$-helix (Figure 5D). While there is a requirement for $\alpha \beta$ TCRs to engage in a canonical orientation (Figure 2A), most likely due to their CD8/CD4 co-factor binding, there might not be such a need for $\gamma \delta$ TCRs. This freedom of docking topology without compromising $\mathrm{T}$ cell signalling, in addition to their high diversity, would increase the number of potential antigens that $\gamma \delta$ T cells can recognise and engage with.

\section{TCR Recognition and T Cell Activation}

A major question in the field of TCR-pMHC recognition is whether we can determine if a $\mathrm{T}$ cell is likely to be activated in response to $\mathrm{pMHC}$ recognition [56]. As such, studies investigating $\mathrm{T}$ cell activation typically correlate common parameters that underpin TCRpMHC interaction, such as docking angles [57], co-factor requirement [15,58,59], association rates $[60,61]$, dissociation rates $[61,62]$, half-life or dwell times $[60,63]$, and even mechanistic interactions [64-68]. As these properties are simplified by the concept of binding affinity, TCR-pMHC interactions are commonly quantified using 3D affinity measurements, such as SPR, that can reveal binding affinity and kinetics. Consistently, high TCR-pMHC affinity has been correlated with $\mathrm{T}$ cell activation [59,69-74]. Exceptions to this have also been discovered, revealing a portion of $\mathrm{T}$ cells that are able to recognise and bind to pMHC but cannot induce $\mathrm{T}$ cell activation $[57,75,76]$.

In a study by Sibener et al., $\mathrm{T}$ cells were able to bind to fluorescently labelled pMHC tetramer with high affinity but were unable to elicit a $\mathrm{T}$ cell response (non-agonist) or able to be stimulated (agonist) [76]. From those T cells, the TCRs TCR6 (agonist, $\mathrm{K}_{\mathrm{d}}$ of $10 \mu \mathrm{M}$ ) and TCR11 (non-agonist, $\mathrm{K}_{\mathrm{d}}$ of $1 \mu \mathrm{M}$ ) were isolated [76]. Both TCRs were specific for the same pHLA-II complex; however, only TCR6 was able to be activated [76]. Similarly, another agonist/non-agonist TCR pair, specific for a pHLA-I, named HLA-B*35:01-IPL, was also studied, and its structures were determined (Table 1). Both the agonist TCR $\alpha \beta$ (TCR589 [76]) and non-agonist TCR $\gamma \delta$ (TU55 or TCR55 [18,76]) bind with similar docking angles onto HLA-B*35:01-IPL and had similar binding affinities, albeit slower dissociation rates for the agonist TCR589 [76]. Using these two sets of agonist/non-agonist TCRs [76], the authors revealed that only the agonist TCRs (TCR6 and TCR589) could form catch bonds. The measure of bond lifetime or dissociation lifetime between TCR-pMHC interactions, which are increased (catch bonds) or decreased (slip bonds) when force is applied [65], was the underlying factor for T cell activation [76]. Taken together, this supports that 2D affinity (cell-to-cell) rather than 3D affinity (SPR) is perhaps a better reflection of the TCR-pMHC interface, and a better correlate for $\mathrm{T}$ cell activation. As such, $\mathrm{T}$ cell activation is driven by cell-to-cell interaction where traditional determinants of TCR affinity (determined by SPR) may be overruled by cellular factors such as TCR expression level, TCR clustering, and pMHC density and stability, which ultimately play a role in avidity.

Many studies over the past several decades have also investigated features of $\mathrm{pMHC}$ molecules that correlate to immunogenicity, i.e., the likelihood that the molecular and structural characteristics of antigen presentation may elicit $\mathrm{T}$ cell activation. These studies have been shown to correlate $\mathrm{pMHC}$ immunogenicity and immunodominance to properties such as pMHC stability [77-81], pMHC dissociation rates [82,83], pMHC density [84], and presence of specific peptide motifs [85]. 
Although looking at immunogenicity predictors solely from the pMHC perspective can be useful in understanding activation, it only considers one side of the interaction. Structures of pMHC molecules have been traditionally used to provide insight into how antigenic peptides are displayed by MHC. However, pMHCs have been shown to be highly dynamic and may not interact in a way that we can predict. For example, Coles and colleagues structurally characterised 3 TCRs $(\mathrm{S} 1, \mathrm{~S} 2, \mathrm{~S} 3)$ specific for the heterocyclic peptide variant of NY-ESO-1, SLLMWITQV, presented by the HLA-A*02:01 molecule [86]. The NYE_S1, NYE_S2, and NYE_S3 TCRs bound the pHLA with a $k_{\mathrm{d}}$ of 7.0, 7.1, and $>82 \mu \mathrm{m}$, respectively, with fast kinetics [86].

The TCRs bind with a similar docking angle and footprints with a centred pHLA mode of binding. The structures for NYE_S1 and NYE_S2 TCRs show recognition of a bulged peptide peg motif (P4-Met and P5-Trp). Interestingly, the structure for NYE_S3 TCR displayed a novel peptide conformation despite sharing binding to the same centric peptide residues. Upon binding of NYE_S3 TCR, the presentation of centric peptide residues (P5Trp and P6-Ile) were flipped upon NYE_S3 TCR binding, resulting in P5-Trp to become buried in HLA-A*02:01 cleft and P6-Ile side chain to interact with NYE_S3 TCR. Despite an 11-fold decrease in affinity for NYE_S3 TCR compared to the other TCRs (Table 1), the corresponding T cell was activated (IFN $\gamma$ release). This shows, again, the difference in TCR affinity does not always differentiate the likelihood of $\mathrm{T}$ cell activation. Furthermore, this study highlights the dynamic nature of pMHC molecules and that additional structural conformations can occur during TCR binding. This is in line with an in silico approach study showing that conformational plasticity within TCR-pMHC-I interactions and also peptide-MHC-I interactions initially thought to stabilise the complex were only transient and actually prone to high flexibility [87].

\section{Conclusions}

The last five years have been the most prolific years for the field of TCR-pMHC-I structures and have greatly expanded the current knowledge on TCR recognition. Structural biology has helped uncover TCR diversity in their docking mode, mechanisms of recognition, and affinity ranges, and we expect that this increase will be sustained over the coming years. This will help us to better understand $\mathrm{T}$ cells and provide much needed information to help fight known or emerging pathogens such as the new coronavirus responsible for the current COVID-19 pandemic. Despite the tremendous effort by so many groups to advance our understanding of TCR recognition and T cell activation, a large amount still remains unclear.

There is a certain lack of diversity within the current database available. For example, only $20 \mathrm{MHC}$ allomorphs have been solved in complex with a TCR, among them only one HLA-C molecule [14], nothing for HLA-G or HLA-F, and only one $\gamma \delta$ TCR [19]. Almost half of the TCR-pMHC-I structures solved involve the HLA-A*02:01 molecule (Table 1, Figure 1D), which is common in Caucasian populations. We hope that future studies will focus on HLAs that have not been extensively studied, which can be applicable for a broader population representing a true cohort of the world's population, providing meaningful and insightful perspectives into TCR recognition and its medical applications.

The recent structure of CD3-TCR complex helps us understand how this amazing machinery comes together [88]. It will now be required for us to gain an insight into the dynamic changes occurring upon TCR engagement, as well as the requirement for $\mathrm{T}$ cell activation, in order to fully appreciate the intricate and specific nature of TCR recognition. Recent examples, such as the novel reverse docking TCRs, provide the tools to deconvolute and uncouple TCR docking and T cell activation [15], which will help clarify key information on $\mathrm{T}$ cell selection and activation. While the field has been focused on highly represented TCRs within the immune repertoire, sometimes public or biased, there are certainly a lot of value and information to gain from less represented T cells.

The studies discussed thus far have mostly attempted to isolate specific parameters that may induce $\mathrm{T}$ cell receptor signalling from peptide-MHC binding in select systems 
involving only a handful of TCRs or a specific pMHC molecule. The search for a unifying parameter that underpins $\mathrm{T}$ cell activation from all studied $\mathrm{pMHC}$ profiles has never been attempted. Interestingly, a study looking at grouping TCRs on the basis of epitope-specific repertoires was able to do so by and clustering or distancing TCRs using a distance-based classifier on the basis of shared motifs and comparing amino acids sequences within CDR loop regions for multiple pMHC systems [89]. Although the study did not directly look at $\mathrm{T}$ cell activation, one could expect that only a portion of TCRs within each distinct cluster would lead to T cell activation, whilst the rest may be inhibited by poor interactions. As such, this tool provides a means to be able to investigate distinct TCR repertoires towards multiple pMHC systems.

Despite efforts to compare the biochemical and structural parameters of all existing TCR-pMHC interactions, we are still at a loss for determining a unified correlate that leads to effective $\mathrm{T}$ cell activation. Interestingly, our analysis of the parameters listed in Table 1 have revealed that there is a correlation between the peptide contribution and BSA, as well as between TCR affinity and BSA (Figure 6). The correlation between the peptide contribution and BSA is inversely proportional. As the peptide presented by MHC-I molecule is limited in length due to the closed end of the MHC-I cleft (Figure 1A), the overall peptide surface is also limited by the volume of the MHC antigen-binding cleft. Therefore, if the overall contact surface at the TCR and pMHC-I interface increases, it is mainly due to an increase of MHC-I BSA, which will in turn decrease the peptide contribution (Figure 6B). We found a significant positive correlation between the TCR affinity and the TCR-pMHC-I BSA, although one could expect that an increase in the number of molecular interactions and contacts, no matter their strength, could potentially contribute and accumulate towards a higher affinity (Figure 6D). As affinity is an important parameter for $\mathrm{T}$ cell activation, but not the sole driver, we here present a direct link between the structural parameters of the TCR-pMHC-I complexes that impact T cell function. Future studies would benefit from an integration of the structural and functional parameters to uncover the link between TCR recognition and T cell activation.
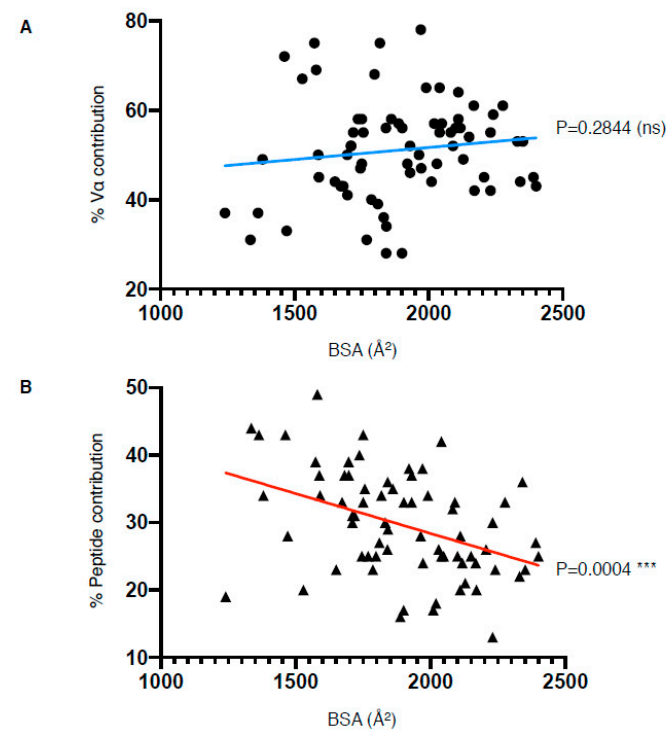

C

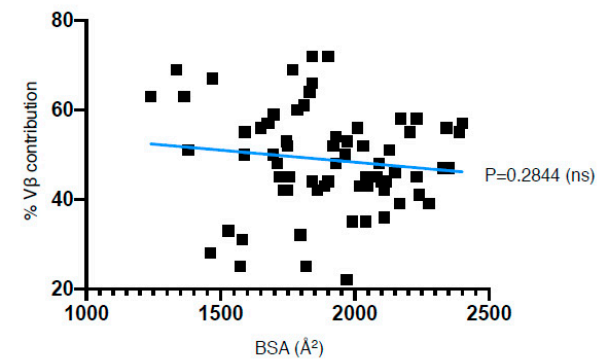

D

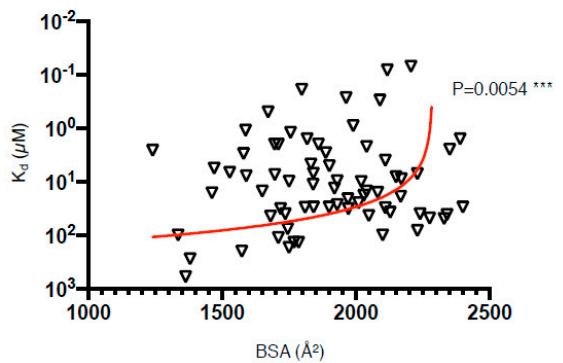

Figure 6. TCR-pMHC-I structural and biophysical parameter correlation. (A-D) Correlation between buried surface area (BSA); contribution from the $\mathrm{V} \alpha, \mathrm{V} \beta$, or peptide; as well as affinity (Kd) were assessed using simple linear regression calculated with Prism 8 ( $p \leq 0.05$ is considered as significant, ns: $p>0.05^{* * *}: p \leq 0.001$ ). Derived function is coloured red if the correlation is significant and blue if not significant. The TCR-pMHC-I complexes without reported affinity (NA in Table 1) were removed as well as the engineered high affinity MAG-IC3 TCR to keep only naturally occurring TCR. 
Table 1. All unique TCR-pMHC-I structures available.

\begin{tabular}{|c|c|c|c|c|c|c|c|c|c|c|c|c|c|}
\hline MHC & Peptide & TCR & TRAV & TRBV & PDB & $\operatorname{CDR} 3 \alpha$ & CDR3 $\beta$ & $\begin{array}{l}\text { BSA } \\
\left(\AA^{2}\right)\end{array}$ & $\begin{array}{l}\mathrm{V} \alpha \\
(\%)\end{array}$ & $\begin{array}{l}V \beta \\
(\%)\end{array}$ & $\begin{array}{l}\text { Pep } \\
\text { (\%) }\end{array}$ & $\begin{array}{c}\mathrm{Kd} \\
(\mu \mathrm{M})\end{array}$ & Ref \\
\hline $\begin{array}{c}\text { HLA- } \\
\mathrm{A}^{*} 02: 01\end{array}$ & $\begin{array}{c}\text { LLFGYPVYV } \\
\text { (HTLV) }\end{array}$ & A6 & $12-2^{*} 02$ & $6-5^{*} 01$ & $1 \mathrm{AO} 7$ & AVTTDSWGKLQ & ASRPGLAGGRPEQY & 1990 & 65 & 35 & 34 & 0.9 & [8] \\
\hline $\begin{array}{c}\text { HLA- } \\
\mathrm{A}^{*} 02: 01 \\
\end{array}$ & $\begin{array}{c}\text { LLFGYPVYV } \\
\text { (HTLV) }\end{array}$ & B7 & 29/DV5*01 & $6-5^{*} 01$ & 1BD2 & AAMEGAQKLV & ASSYPGGGFYEQY & 1710 & 68 & 32 & 32 & ND & [90] \\
\hline $\mathrm{H} 2-\mathrm{Kb}$ & EQYKFYSV (self) & $2 \mathrm{C}$ & $9-4 * 01$ & $13-2 * 01$ & $2 \mathrm{CKB}$ & AVSGFASALT & ASGGGGTLY & 2100 & 56 & 44 & 25 & 100 & [91] \\
\hline $\mathrm{H} 2-\mathrm{Kb}$ & INFDFNTI (self) & BM3.3 & 16/DV11*01 & $1 * 01$ & $1 \mathrm{FO} 0$ & AMRGDYGGSGNKLI & TCSADRVGNTLY & 1240 & 37 & 63 & 19 & 2.6 & [92] \\
\hline $\mathrm{H} 2-\mathrm{Kb}$ & KVITFIDL (self) & KB5-C20 & $14-1^{*} 01$ & $1 * 01$ & $1 \mathrm{KJ} 2$ & AARYQGGRALI & TCSAAPDWGASAETLY & 1890 & 48 & 52 & 21 & ND & [93] \\
\hline $\begin{array}{c}\text { HLA- } \\
A^{*} 02: 01\end{array}$ & ALWGFFPVL (self) & $\begin{array}{c}\text { AHIII } \\
12.2\end{array}$ & $12 \mathrm{D}-2 * 01$ & $13-3^{*} 01$ & $1 \mathrm{LP9}$ & ALFLASSSFSKLV & ASSDWVSYEQY & 1840 & 56 & 44 & 26 & 11.3 & [94] \\
\hline $\begin{array}{c}\text { HLA- } \\
B^{*} 08: 01\end{array}$ & FLRGRAYGL (EBV) & LC13 & $26-2^{*} 01$ & $7-8^{*} 01$ & $1 \mathrm{MI} 5$ & ILPLAGGTSYGKLT & ASSLGQAYEQY & 2020 & 57 & 43 & 18 & 10 & [45] \\
\hline 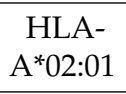 & $\begin{array}{l}\text { GILGFVFTL } \\
\text { (Influenza) }\end{array}$ & JM22 & $27^{*} 01$ & 19-01 & 1OGA & AGAGSQGNLI & ASSSRSSYEQY & 1470 & 33 & 67 & 28 & 5.6 & [34] \\
\hline $\begin{array}{c}\text { HLA- } \\
B^{* 35: 08}\end{array}$ & $\begin{array}{c}\text { LPEPLPQGQLTAY } \\
(\text { EBV) }\end{array}$ & SB27 & $19 * 01$ & $6-1 * 01$ & $2 \mathrm{AK} 4$ & ALSGFYNTDKLI & ASPGLAGEYEQY & 1750 & 58 & 42 & 43 & 9.9 & [95] \\
\hline 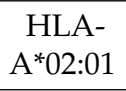 & SLLMWITQC (self) & $1 \mathrm{G} 4$ & $21^{*} 01$ & $6-5^{*} 01$ & 2BNR & AVRPTSGGSYIPT & ASSYVGNTGELF & 1920 & 48 & 52 & 38 & 13.3 & [96] \\
\hline $\begin{array}{c}\text { HLA- } \\
E^{*} 01: 03\end{array}$ & $\begin{array}{l}\text { VMAPRTLIL } \\
(\mathrm{CMV})\end{array}$ & KK50.4 & $26-1^{*} 01$ & $14^{*} 01$ & 2ESV & IVVRSSNTGKLI & ASSQDRDTQY & 1810 & 39 & 61 & 27 & 30.2 & [97] \\
\hline $\begin{array}{c}\text { HLA- } \\
B^{* 35: 01}\end{array}$ & $\begin{array}{l}\text { EPLPQGQLTAY } \\
\text { (EBV) }\end{array}$ & ELS4 & $1-2 * 01$ & $10-3^{*} 01$ & $2 \mathrm{NX} 5$ & AVQASGGSYIPT & ATGTGDSNQPQH & 2400 & 43 & 57 & 25 & 30 & [98] \\
\hline H2-Ld2 & $\begin{array}{l}\text { QLSPFPFDL } \\
\text { (synthetic) }\end{array}$ & $2 \mathrm{C}$ & $9-4 * 01$ & $13-2^{*} 01$ & $2 \mathrm{OI} 9$ & AVSGFASALT & ASGGGGTLY & 1710 & 52 & 48 & 31 & 2 & [99] \\
\hline $\begin{array}{c}\mathrm{H} 2- \\
\mathrm{Kbm} 8\end{array}$ & $\begin{array}{l}\text { SQYYYNSL } \\
\text { (synthetic) }\end{array}$ & BM3.3 & 16/DV11*01 & $1 * 01$ & $2 \mathrm{OL3}$ & AMRGDYGGSGNKLI & TCSADRVGNTLY & 1710 & 52 & 48 & 30 & 112 & {$[100]$} \\
\hline $\begin{array}{c}\text { HLA- } \\
B^{*} 44: 05\end{array}$ & $\begin{array}{c}\text { EENLLDFVRF } \\
(\mathrm{EBV})\end{array}$ & $\mathrm{DM}$ & $26-1 * 02$ & $7-9 * 01$ & 3DXA & IVWGGYQKVT & ASRYRDDSYNEQF & 2090 & 52 & 48 & 33 & 0.3 & [101] \\
\hline $\begin{array}{c}\text { HLA- } \\
B^{*} 08: 01\end{array}$ & FLRGRAYGL (EBV) & CF34 & $14 / \mathrm{DV} 4 * 01$ & $11-2^{*} 01$ & 3FFC & AMREDTGNFY & ASSFTWTSGGATDTQY & 2170 & 42 & 58 & 20 & 8.9 & [102] \\
\hline
\end{tabular}


Table 1. Cont.

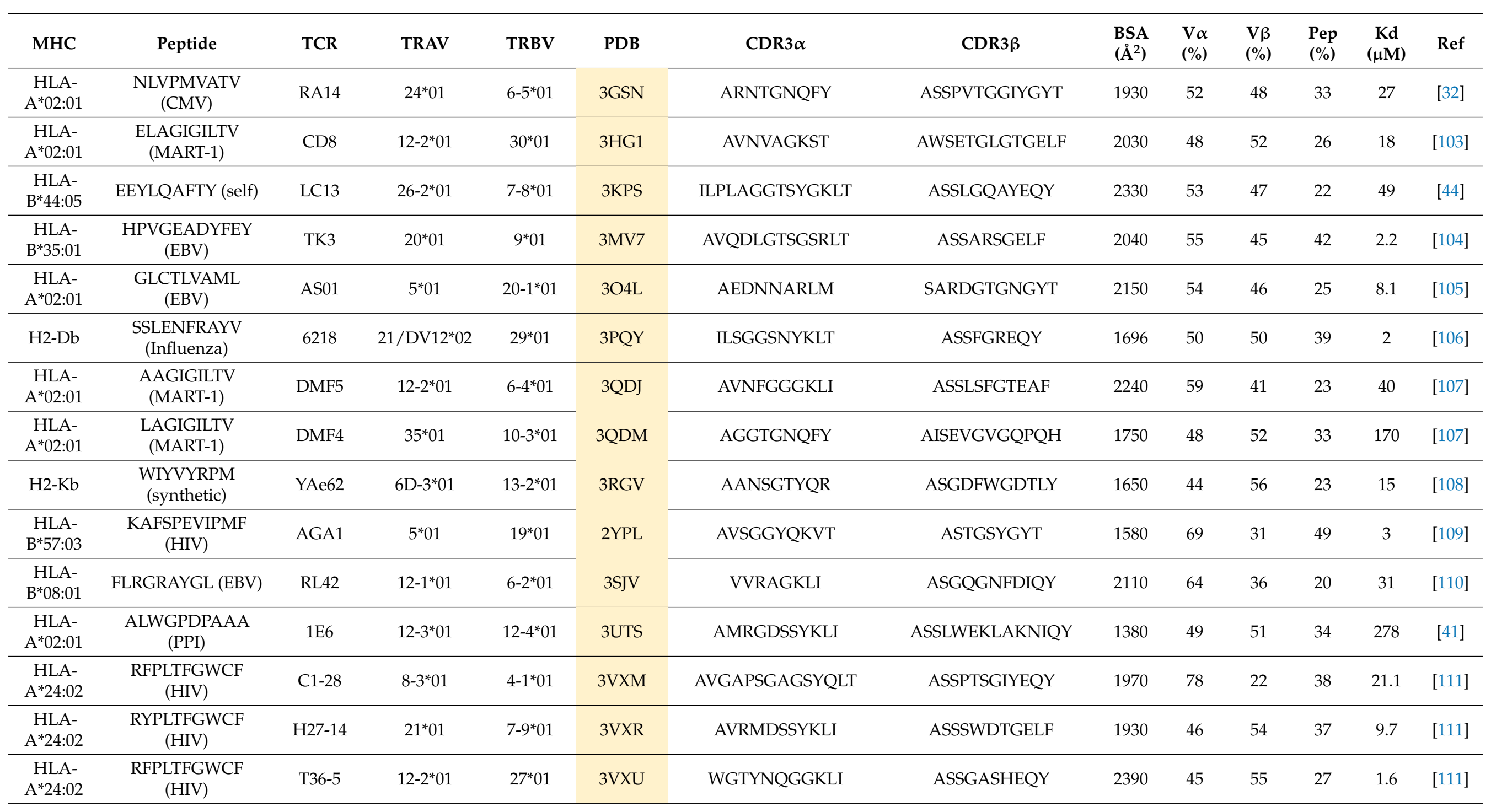


Table 1. Cont.

\begin{tabular}{|c|c|c|c|c|c|c|c|c|c|c|c|c|c|}
\hline MHC & Peptide & TCR & TRAV & TRBV & PDB & $\operatorname{CDR} 3 \alpha$ & CDR3 $\beta$ & $\begin{array}{l}\text { BSA } \\
\left(\AA^{2}\right)\end{array}$ & $\begin{array}{l}\mathrm{V} \alpha \\
(\%)\end{array}$ & $\begin{array}{l}\mathrm{V} \beta \\
(\%)\end{array}$ & $\begin{array}{l}\text { Pep } \\
(\%)\end{array}$ & $\begin{array}{c}\mathrm{Kd} \\
(\mu \mathrm{M})\end{array}$ & Ref \\
\hline $\begin{array}{c}\text { HLA- } \\
B^{*} 27: 05\end{array}$ & $\begin{array}{l}\text { KRWIILGLNK } \\
\text { (HIV) }\end{array}$ & $\mathrm{C} 12 \mathrm{C}$ & $14 / \mathrm{DV} 44^{*} 02$ & $6-5^{*} 01$ & $4 \mathrm{G} 8 \mathrm{G}$ & AMRDLRDNFNKFY & ASREGLGGTEAF & 1860 & 58 & 42 & 35 & 2 & [112] \\
\hline $\begin{array}{c}\text { HLA- } \\
B^{*} 35: 08\end{array}$ & $\begin{array}{c}\text { LPEPLPQGQLTAY } \\
\text { (EBV) }\end{array}$ & SB47 & $39 * 01$ & $5-6^{*} 01$ & 4JRY & AVGGGSNYQLI & ASSRTGSTYEQY & 2010 & 44 & 56 & 17 & 25 & [113] \\
\hline $\begin{array}{c}\text { HLA- } \\
B^{*} 51: 01\end{array}$ & TAFTIPSI (HIV) & $3 B$ & $17^{*} 01$ & $7-3^{*} 01$ & $4 \mathrm{MJI}$ & ATDDDSARQLT & ASSLTGGGELF & 2230 & 55 & 45 & 13 & 81.8 & [114] \\
\hline $\begin{array}{c}\text { HLA- } \\
\mathrm{B}^{*} 08: 01\end{array}$ & $\begin{array}{c}\text { HSKKKCDEL } \\
(\mathrm{HCV})\end{array}$ & DD31 & $9-2 * 01$ & $11-2^{*} 01$ & $4 \mathrm{QRP}$ & ALSDPVNDMR & ASSLRGRGDQPQH & 2351 & 53 & 47 & 23 & 2.5 & [115] \\
\hline H2-Ld2 & $\begin{array}{l}\text { GAPWNPAMMI } \\
\text { (p3M11I) }\end{array}$ & M33 & $9-4^{*} 01$ & $13-2^{*} 01$ & $4 \mathrm{NHU}$ & AVSLHRPALT & ASGGGGTLY & 1504 & 71 & 29 & 18 & ND & [NA] \\
\hline $\begin{array}{c}\text { HLA- } \\
A^{*} 02: 01\end{array}$ & $\begin{array}{l}\text { NLVPMVATV } \\
\text { (CMV) }\end{array}$ & C7 & $24^{*} 01$ & $7-2 * 02$ & 5D2L & AFITGNQFY & ASSQTQLWETQY & 1901 & 56 & 44 & 33 & 5.1 & [33] \\
\hline $\begin{array}{c}\text { HLA- } \\
\mathrm{A}^{*} 02: 01\end{array}$ & $\begin{array}{l}\text { NLVPMVATV } \\
\text { (CMV) }\end{array}$ & $\mathrm{C} 25$ & $26-2^{*} 01$ & $7-6^{*} 01$ & $5 \mathrm{D} 2 \mathrm{~N}$ & ILDNNNDMR & ASSLAPGTTNEKLF & 1832 & 36 & 64 & 30 & 4.7 & [33] \\
\hline $\begin{array}{c}\text { HLA- } \\
\mathrm{A}^{*} 01: 01\end{array}$ & $\begin{array}{c}\text { EVDPIGHLY } \\
\text { (MAGE-A3) }\end{array}$ & $\begin{array}{l}\text { MAG- } \\
\text { IC3 }\end{array}$ & $21^{*} 01$ & $5-1^{*} 01$ & $5 \mathrm{BRZ}$ & AVRPGGAGPFFVV & ASSFNMATGQY & 1817 & 62 & 38 & 22 & 0.0071 & [9] \\
\hline $\begin{array}{c}\text { HLA- } \\
A^{*} 01: 01\end{array}$ & ESDPIVAQY (Titin) & $\begin{array}{l}\text { MAG- } \\
\text { IC3 }\end{array}$ & $21 * 01$ & $5-1 * 01$ & 5BS0 & AVRPGGAGPFFVV & ASSFNMATGQY & 2048 & 58 & 42 & 26 & 0.0767 & [9] \\
\hline $\begin{array}{c}\text { HLA- } \\
A^{* 02: 01}\end{array}$ & $\begin{array}{c}\text { YQFGPDFPIA } \\
\text { (synthetic) }\end{array}$ & $1 \mathrm{E} 6$ & $12-3^{*} 01$ & $12-4^{*} 01$ & $5 \mathrm{C} 07$ & AMRGDSSYKLI & ASSLWEKLAKNIQY & 1697 & 41 & 59 & 37 & 7.4 & [20] \\
\hline 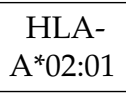 & $\begin{array}{l}\text { RQWGPDPAAV } \\
\text { (synthetic) }\end{array}$ & $1 \mathrm{E} 6$ & $12-3^{*} 01$ & $12-4^{*} 01$ & $5 \mathrm{C} 08$ & AMRGDSSYKLI & ASSLWEKLAKNIQY & 1590 & 45 & 55 & 34 & 7.8 & [20] \\
\hline $\begin{array}{c}\text { HLA- } \\
A^{*} 02: 01\end{array}$ & $\begin{array}{l}\text { MVWGPDPLYV (B. } \\
\text { fragilis) }\end{array}$ & $1 \mathrm{E} 6$ & $12-3^{*} 01$ & $12-4^{*} 01$ & $5 \mathrm{C} 0 \mathrm{~A}$ & AMRGDSSYKLI & ASSLWEKLAKNIQY & 1364 & 37 & 63 & 43 & 600 & [20] \\
\hline 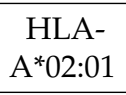 & $\begin{array}{c}\text { RQFGPDFPTI (C. } \\
\text { asparagiforme) }\end{array}$ & $1 \mathrm{E} 6$ & $12-3^{*} 01$ & $12-4^{*} 01$ & $5 \mathrm{COB}$ & AMRGDSSYKLI & ASSLWEKLAKNIQY & 1672 & 43 & 57 & 33 & 0.5 & [20] \\
\hline $\begin{array}{c}\text { HLA- } \\
\mathrm{A}^{*} 02: 01\end{array}$ & $\begin{array}{l}\text { RQFGPDWIVA } \\
\text { (synthetic) }\end{array}$ & $1 \mathrm{E} 6$ & $12-3^{*} 01$ & $12-4^{*} 01$ & $5 \mathrm{C} 0 \mathrm{C}$ & AMRGDSSYKLI & ASSLWEKLAKNIQY & 1681 & 43 & 57 & 37 & 44.4 & [20] \\
\hline
\end{tabular}


Table 1. Cont.

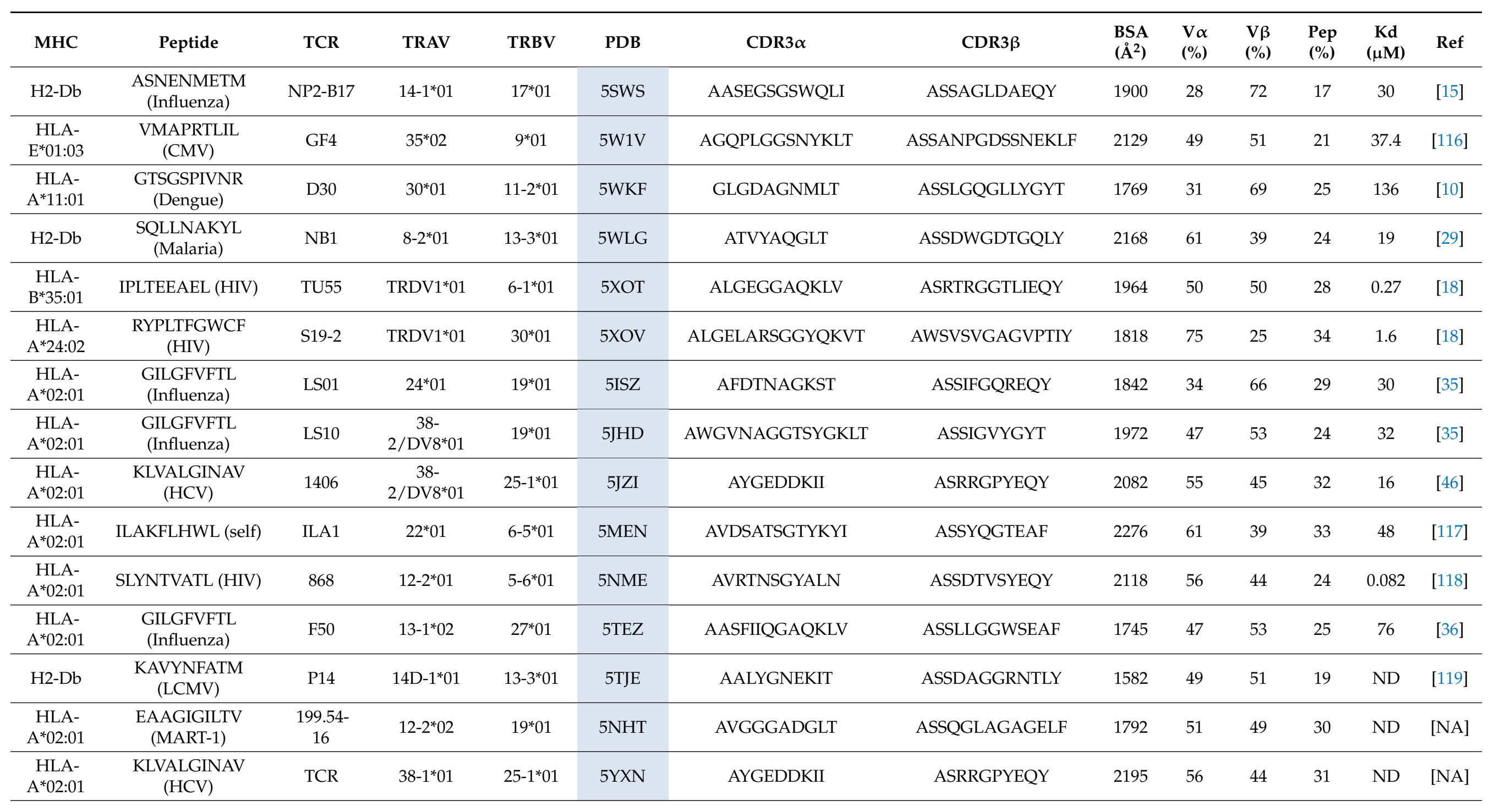


Table 1. Cont.

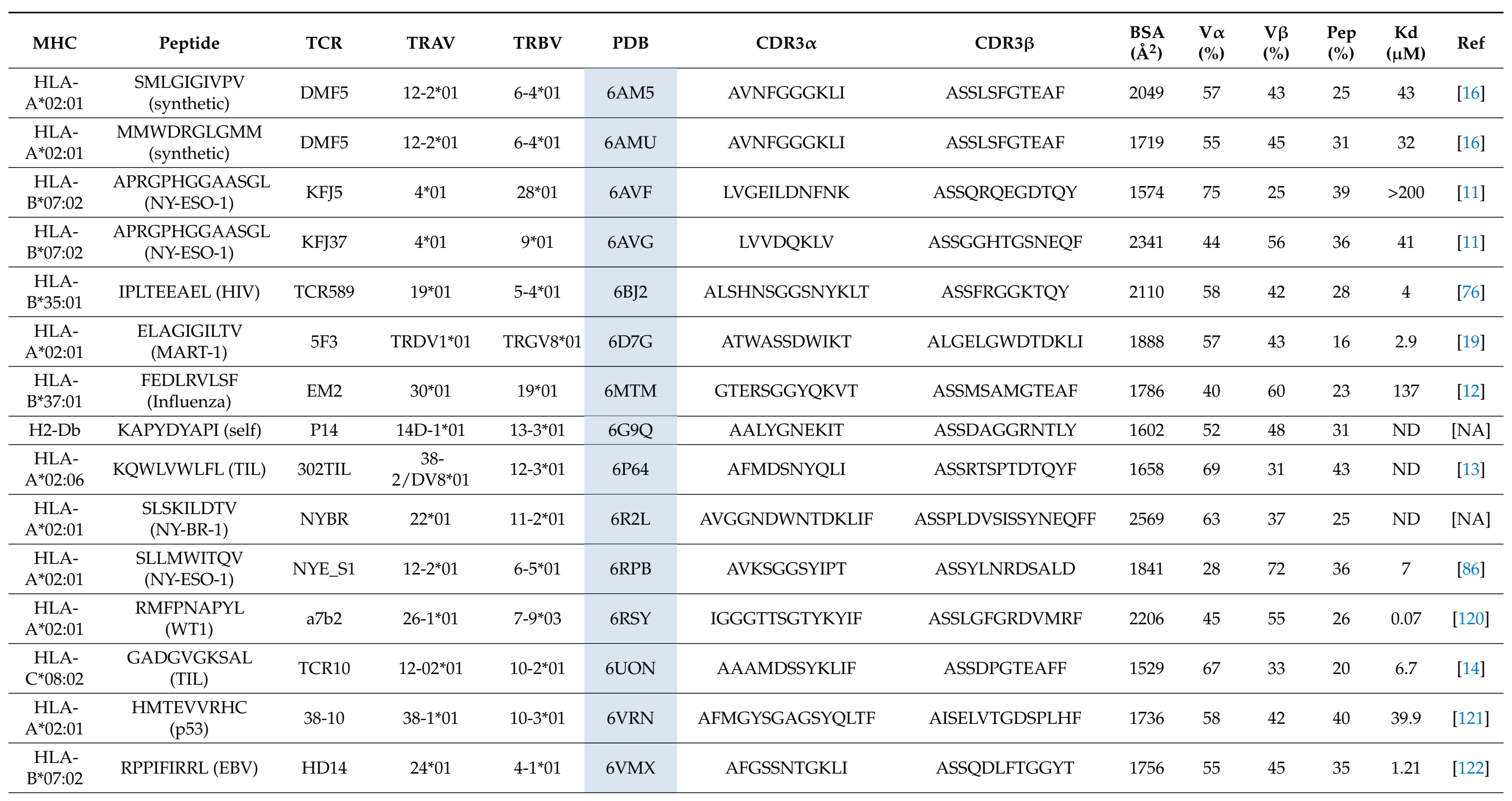


Table 1. Cont.

\begin{tabular}{|c|c|c|c|c|c|c|c|c|c|c|c|c|c|}
\hline MHC & Peptide & TCR & TRAV & TRBV & PDB & $\operatorname{CDR} 3 \alpha$ & CDR3 $\beta$ & $\begin{array}{l}\text { BSA } \\
\left(\AA^{2}\right)\end{array}$ & $\begin{array}{l}\mathrm{V} \alpha \\
(\%)\end{array}$ & $\begin{array}{l}V \beta \\
(\%)\end{array}$ & $\begin{array}{l}\text { Pep } \\
\text { (\%) }\end{array}$ & $\begin{array}{c}\mathrm{Kd} \\
(\mu \mathrm{M})\end{array}$ & Ref \\
\hline $\begin{array}{c}\text { HLA- } \\
\mathrm{A}^{*} 02: 01\end{array}$ & $\begin{array}{l}\text { SLLMWITQV } \\
\text { (NY-ESO-1) }\end{array}$ & NYE_S3 & $12-2 * 01$ & $7-6^{*} 01$ & 6RP9 & ALTRGPGNQFY & ASSSPGGVSTEAF & 1335 & 31 & 69 & 44 & $>82$ & [86] \\
\hline $\begin{array}{c}\text { HLA- } \\
\text { A*02:01 }^{*}\end{array}$ & $\begin{array}{l}\text { SLLMWITQV } \\
\text { (NY-ESO-1) }\end{array}$ & NYE_S2 & $3^{*} 01$ & $29-1^{*} 01$ & 6RPA & AVRDINSGAGSYQLT & SVGGSGGADTQY & 2230 & 42 & 58 & 30 & 7.1 & [86] \\
\hline $\begin{array}{c}\text { HLA- } \\
A^{* 02: 01}\end{array}$ & $\begin{array}{c}\text { GVYDGREHTV } \\
\text { (MAGE-4) }\end{array}$ & GVY01 & $10 * 01$ & $28^{*} 01$ & $6 \mathrm{TRO}$ & VVNHSGGSYIPTF & ASSFLMSGDPYEQYF & 1798 & 68 & 32 & 25 & 0.19 & {$[123]$} \\
\hline \multirow[t]{2}{*}{$\begin{array}{c}\text { HLA- } \\
A^{* 02: 01}\end{array}$} & $\begin{array}{l}\text { HMTEVVRHC } \\
\text { (p53) }\end{array}$ & $12-6$ & $12-1 * 01$ & $6-1 * 01$ & 6VRM & VVQPGGYQKVTF & ASSEGLWQVGDEQYF & 1588 & 50 & 50 & 37 & 1.1 & {$[121]$} \\
\hline & & & & & & & Average & 1885 & 52 & 48 & 29 & 40 & \\
\hline
\end{tabular}

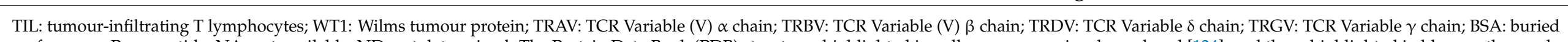

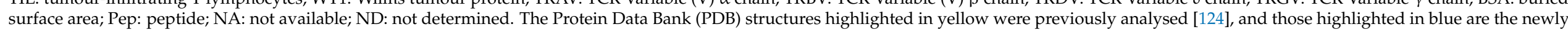
analysed structures in this review. 
Author Contributions: C.S., C.A.L., A.T.N., and S.G. all searched the literature, curated and analysed the structures, and wrote the manuscript. All authors have read and agreed to the published version of the manuscript.

Funding: This work was supported by NHMRC S.G. is supported by NHMRC SRF (\#1159272).

Acknowledgments: The authors would like to thank all their colleagues in the field contributing to our current understanding at the molecular level to TCR recognition of pMHC complexes.

Conflicts of Interest: The authors declare no conflict of interest.

\section{References}

1. Josephs, T.M.; Grant, E.J.; Gras, S. Molecular challenges imposed by MHC-I restricted long epitopes on T cell immunity. Biol. Chem. 2017, 398, 1027-1036. [CrossRef] [PubMed]

2. McCluskey, J.; Gras, S.; Bharadwaj, M.; Kjer-Nielsen, L. HLA Molecules of the Major Histocompatibility Complex. In The HLA Complex in Biology and Medicine: A Resource Book; Jaypee Brothers Medical Publishing: New Delhi, India, $2010 ;$ p. 86.

3. Sette, A.; Sidney, J. Nine major HLA class I supertypes account for the vast preponderance of HLA-A and -B polymorphism. Immunogenetics 1999, 50, 201-212. [CrossRef]

4. Lefranc, M.-P. Nomenclature of the human T cell receptor genes. Curr. Protoc. Immunol. 2000, 40, A.1O.1-A.1O.23. [CrossRef]

5. Cabaniols, J.P.; Fazilleau, N.; Casrouge, A.; Kourilsky, P.; Kanellopoulos, J.M. Most alpha/beta T cell receptor diversity is due to terminal deoxynucleotidyl transferase. J. Exp. Med. 2001, 194, 1385. [CrossRef] [PubMed]

6. Davis, M.M.; Bjorkman, P.J. T-cell antigen receptor genes and T-cell recognition. Nat. Cell Biol. 1988, 334, 395-402. [CrossRef]

7. Arstila, T.P.; Casrouge, A.; Baron, V.; Even, J.; Kanellopoulos, J.; Kourilsky, P. A direct estimate of the human alphabeta T cell receptor diversity. Science 1999, 286, 958. [CrossRef] [PubMed]

8. Garboczi, D.N.; Ghosh, P.; Utz, U.; Fan, Q.R.; Biddison, W.E.; Wiley, D.C. Structure of the complex between human T-cell receptor, viral peptide and HLA-A2. Nat. Cell Biol. 1996, 384, 134-141. [CrossRef]

9. Raman, M.C.C.; Rizkallah, P.J.; Simmons, R.; Donnellan, Z.; Dukes, J.D.; Bossi, G.; Provost, G.S.L.; Todorov, P.; Baston, E.; Hickman, E.; et al. Direct molecular mimicry enables off-target cardiovascular toxicity by an enhanced affinity TCR designed for cancer immunotherapy. Sci. Rep. 2016, 6, 18851. [CrossRef]

10. Culshaw, A.; Ladell, K.; Gras, S.; McLaren, J.E.; Miners, K.L.; Farenc, C.; Heuvel, H.V.D.; Gostick, E.; Dejnirattisai, W.; Wangteeraprasert, A.; et al. Germline bias dictates cross-serotype reactivity in a common dengue-virus-specific CD8+ T cell response. Nat. Immunol. 2017, 18, 1228-1237. [CrossRef]

11. Chan, K.F.; Gully, B.S.; Gras, S.; Beringer, D.X.; Kjer-Nielsen, L.; Cebon, J.; McCluskey, J.; Chen, W.; Rossjohn, J. Divergent T-cell receptor recognition modes of a HLA-I restricted extended tumour-associated peptide. Nat. Commun. 2018, 9, 1-13. [CrossRef]

12. Grant, E.J.; Josephs, T.M.; Loh, L.; Clemens, E.B.; Sant, S.; Bharadwaj, M.; Chen, W.; Rossjohn, J.; Gras, S.; Kedzierska, K. Broad CD8+ T cell cross-recognition of distinct influenza A strains in humans. Nat. Commun. 2018, 9, 5427. [CrossRef] [PubMed]

13. Devlin, J.R.; Alonso, J.A.; Ayres, C.M.; Keller, G.L.J.; Bobisse, S.; Kooi, C.W.V.; Coukos, G.; Gfeller, D.; Harari, A.; Baker, B.M. Structural dissimilarity from self drives neoepitope escape from immune tolerance. Nat. Chem. Biol. 2020, 16, $1269-1276$. [CrossRef]

14. Sim, M.J.W.; Lu, J.; Spencer, M.; Hopkins, F.; Tran, E.; Rosenberg, S.A.; Long, E.O.; Sun, P.D. High-affinity oligoclonal TCRs define effective adoptive T cell therapy targeting mutant KRAS-G12D. Proc. Natl. Acad. Sci. USA 2020, 117, 12826. [CrossRef] [PubMed]

15. Gras, S.; Chadderton, J.; Del Campo, C.M.; Farenc, C.; Wiede, F.; Josephs, T.M.; Sng, X.Y.; Mirams, M.; Watson, K.A.; Tiganis, T.; et al. Reversed $\mathrm{t}$ cell receptor docking on a major histocompatibility class I complex limits involvement in the immune response. Immunity 2016, 45, 749-760. [CrossRef] [PubMed]

16. Riley, T.P.; Hellman, L.M.; Gee, M.H.; Mendoza, J.L.; Alonso, J.A.; Foley, K.C.; Nishimura, M.I.; Kooi, C.W.V.; Garcia, K.C.; Baker, B.M. T cell receptor cross-reactivity expanded by dramatic peptide-MHC adaptability. Nat. Chem. Biol. 2018, 14, 934-942. [CrossRef] [PubMed]

17. Pellicci, D.G.; Uldrich, A.P.; Le Nours, J.; Ross, F.; Chabrol, E.; Eckle, S.B.; de Boer, R.; Lim, R.T.; McPherson, K.; Besra, G.; et al. The molecular bases of delta/alphabeta T cell-mediated antigen recognition. J. Exp. Med. 2014, 211, 2599. [CrossRef] [PubMed]

18. Shi, Y.; Kawana-Tachikawa, A.; Gao, F.; Qi, J.; Liu, C.; Gao, J.; Cheng, H.; Ueno, T.; Iwamoto, A.; George, F. Conserved vdelta1 binding geometry in a setting of locus-disparate pHLA recognition by delta/alphabeta T Cell Receptors (TCRs): Insight into recognition of HIV peptides by TCRs. J. Virol. 2017, 91, e00725-17. [CrossRef]

19. Benveniste, P.M.; Roy, S.; Nakatsugawa, M.; Chen, E.L.Y.; Nguyen, L.; Millar, D.G.; Ohashi, P.S.; Hirano, N.; Adams, E.J.; Zúñiga-Pflücker, J.C. Generation and molecular recognition of melanoma-associated antigen-specific human gammadelta T cells. Sci. Immunol. 2018, 3, eaav4036. [CrossRef]

20. Cole, D.K.; Bulek, A.M.; Dolton, G.; Schauenberg, A.J.; Szomolay, B.; Rittase, W.; Trimby, A.; Jothikumar, P.; Fuller, A.; Skowera, A.; et al. Hotspot autoimmune $\mathrm{T}$ cell receptor binding underlies pathogen and insulin peptide cross-reactivity. J. Clin. Investig. 2016, 126, 2191. [CrossRef]

21. Yin, L.; Scott-Browne, J.; Kappler, J.W.; Gapin, L.; Marrack, P. T cells and their eons-old obsession with MHC. Immunol. Rev. 2012, 250, 49-60. [CrossRef] 
22. Feng, D.; Bond, C.J.; Ely, L.K.; Maynard, J.A.; Garcia, K.C. Structural evidence for a germline-encoded T cell receptor-major histocompatibility complex interaction 'codon'. Nat. Immunol. 2007, 8, 975-983. [CrossRef] [PubMed]

23. Birkinshaw, R.W.; Pellicci, D.G.; Cheng, T.Y.; Keller, A.N.; Sandoval-Romero, M.; Gras, S.; de Jong, A.; Uldrich, A.P.; Moody, D.B.; Godfrey, D.I.; et al. Alphabeta T cell antigen receptor recognition of CD1a presenting self lipid ligands. Nat. Immunol. 2015, 16, 258. [CrossRef] [PubMed]

24. López-Sagaseta, J.; Dulberger, C.L.; Crooks, J.E.; Parks, C.D.; Luoma, A.M.; McFedries, A.; Van Rhijn, I.; Saghatelian, A.; Adams, E.J. The molecular basis for mucosal-associated invariant T cell recognition of MR1 proteins. Proc. Natl. Acad. Sci. USA 2013, 110, E1771-E1778. [CrossRef] [PubMed]

25. Patel, O.; Kjer-Nielsen, L.; Le Nours, J.; Eckle, S.B.G.; Birkinshaw, R.; Beddoe, T.; Corbett, A.J.; Liu, L.; Miles, J.J.; Meehan, B.; et al. Recognition of vitamin B metabolites by mucosal-associated invariant T cells. Nat. Commun. 2013, 4, 2142. [CrossRef] [PubMed]

26. Le Nours, J.; Gherardin, N.A.; Ramarathinam, S.H.; Awad, W.; Wiede, F.; Gully, B.S.; Khandokar, Y.; Praveena, T.; Wubben, J.M.; Sandow, J.J.; et al. A class of gammadelta T cell receptors recognize the underside of the antigen-presenting molecule MR1. Science 2019, 366, 1522. [CrossRef]

27. Van Laethem, F.; Sarafova, S.D.; Park, J.H.; Tai, X.; Pobezinsky, L.; Guinter, T.I.; Adoro, S.; Adams, A.; Sharrow, S.O.; Feigenbaum, L.; et al. Deletion of CD4 and CD8 coreceptors permits generation of alphabetaT cells that recognize antigens independently of the MHC. Immunity 2007, 27, 735. [CrossRef]

28. Rangarajan, S.; Mariuzza, R.A. T cell receptor bias for MHC: Co-evolution or co-receptors? Cell. Mol. Life Sci. 2014, 71, 3059-3068. [CrossRef]

29. Van Braeckel-Budimir, N.; Gras, S.; Ladell, K.; Josephs, T.M.; Pewe, L.; Urban, S.L.; Miners, K.L.; Farenc, C.; Price, D.A.; Rossjohn, J.; et al. A T cell receptor locus harbors a malaria-specific immune response gene. Immunity 2017, 47, 835-847.e4. [CrossRef]

30. Ekeruche-Makinde, J.; Miles, J.J.; Berg, H.A.V.D.; Skowera, A.; Cole, D.K.; Dolton, G.; Schauenburg, A.J.A.; Tan, M.P.; Pentier, J.M.; Llewellyn-Lacey, S.; et al. Peptide length determines the outcome of TCR/peptide-MHCI engagement. Blood 2013, 121, 1112-1123. [CrossRef]

31. Gras, S. Flipping out the peptide. Nat. Chem. Biol. 2018, 14, 905-906. [CrossRef]

32. Gras, S.; Saulquin, X.; Reiser, J.-B.; Debeaupuis, E.; Echasserieau, K.; Kissenpfennig, A.; Legoux, F.; Chouquet, A.; Le Gorrec, M.; Machillot, P.; et al. Structural bases for the affinity-driven selection of a public TCR against a dominant human cytomegalovirus epitope. J. Immunol. 2009, 183, 430-437. [CrossRef] [PubMed]

33. Yang, X.; Gao, M.; Chen, G.; Pierce, B.G.; Lu, J.; Weng, N.-P.; Mariuzza, R.A. Structural basis for clonal diversity of the public T cell response to a dominant human cytomegalovirus epitope. J. Biol. Chem. 2015, 290, 29106-29119. [CrossRef]

34. Stewart-Jones, G.B.E.; McMichael, A.J.; Bell, J.I.; Stuart, D.I.; Jones, E.Y. A structural basis for immunodominant human T cell receptor recognition. Nat. Immunol. 2003, 4, 657-663. [CrossRef] [PubMed]

35. Song, I.; Gil, A.; Mishra, R.; Ghersi, D.; Selin, L.K.; Stern, L.J. Broad TCR repertoire and diverse structural solutions for recognition of an immunodominant CD8+ T cell epitope. Nat. Struct. Mol. Biol. 2017, 24, 395-406. [CrossRef] [PubMed]

36. Yang, X.; Chen, G.; Weng, N.-P.; Mariuzza, R.A. Structural basis for clonal diversity of the human T-cell response to a dominant influenza virus epitope. J. Biol. Chem. 2017, 292, 18618-18627. [CrossRef] [PubMed]

37. Thomas, R.; Al-Khadairi, G.; Roelands, J.; Hendrickx, W.; Dermime, S.; Bedognetti, D.; Decock, J. NY-ESO-1 Based Immunotherapy of Cancer: Current Perspectives. Front. Immunol. 2018, 9, 947. [CrossRef]

38. Raza, A.; Merhi, M.; Inchakalody, V.P.; Krishnankutty, R.; Relecom, A.; Uddin, S.; Dermime, S. Unleashing the immune response to NY-ESO-1 cancer testis antigen as a potential target for cancer immunotherapy. J. Transl. Med. 2020, 18, 1-11. [CrossRef]

39. Sewell, A.K. Why must T cells be cross-reactive? Nat. Rev. Immunol. 2012, 12, 669-677. [CrossRef]

40. Rojas, M.; Restrepo-Jiménez, P.; Monsalve, D.M.; Pacheco, Y.; Acosta-Ampudia, Y.; Ramírez-Santana, C.; Leung, P.S.; Ansari, A.A.; Gershwin, M.E.; Anaya, J.-M. Molecular mimicry and autoimmunity. J. Autoimmun. 2018, 95, 100-123. [CrossRef]

41. Bulek, A.M.; Cole, D.K.; Skowera, A.; Dolton, G.; Gras, S.; Madura, F.; Fuller, A.; Miles, J.J.; Gostick, E.; Price, D.A.; et al. Structural basis for the killing of human beta cells by CD8+ T cells in type 1 diabetes. Nat. Immunol. 2012, 13, 283-289. [CrossRef]

42. Linette, G.P.; Stadtmauer, E.A.; Maus, M.V.; Rapoport, A.P.; Levine, B.L.; Emery, L.; Litzky, L.; Bagg, A.; Carreno, B.M.; Cimino, P.J.; et al. Cardiovascular toxicity and titin cross-reactivity of affinity-enhanced T cells in myeloma and melanoma. Blood 2013, 122, 863-871. [CrossRef] [PubMed]

43. Rowntree, L.C.; Nguyen, T.H.; Gras, S.; Kotsimbos, T.C.; Mifsud, N.A. Deciphering the clinical relevance of allo-human leukocyte antigen cross-reactivity in mediating alloimmunity following transplantation. Curr. Opin. Organ Transplant. 2016, 21, 29-39. [CrossRef] [PubMed]

44. Macdonald, W.A.; Chen, Z.; Gras, S.; Archbold, J.K.; Tynan, F.E.; Clements, C.S.; Bharadwaj, M.; Kjer-Nielsen, L.; Saunders, P.M.; Wilce, M.C.; et al. T Cell Allorecognition via Molecular Mimicry. Immunity 2009, 31, 897-908. [CrossRef] [PubMed]

45. Kjer-Nielsen, L.; Clements, C.S.; Purcell, A.W.; Brooks, A.G.; Whisstock, J.C.; Burrows, S.R.; McCluskey, J.; Rossjohn, J. A structural basis for the selection of dominant alphabeta T cell receptors in antiviral immunity. Immunity 2003, 18, 53. [CrossRef]

46. Wang, Y.; Singh, N.K.; Spear, T.T.; Hellman, L.M.; Piepenbrink, K.H.; Mcmahan, R.H.; Rosen, H.R.; Kooi, C.W.V.; Nishimura, M.I.; Baker, B.M. How an alloreactive T-cell receptor achieves peptide and MHC specificity. Proc. Natl. Acad. Sci. USA 2017, 114, E4792-E4801. [CrossRef] [PubMed]

47. Gras, S.; Kjer-Nielsen, L.; Chen, Z.; Rossjohn, J.; McCluskey, J. The structural bases of direct T-cell allorecognition: Implications for T-cell-mediated transplant rejection. Immunol. Cell Biol. 2011, 89, 388. [CrossRef] 
48. Valkenburg, S.A.; Josephs, T.M.; Clemens, E.B.; Grant, E.J.; Nguyen, T.H.O.; Wang, G.C.; Price, D.A.; Miller, A.; Tong, S.Y.C.; Thomas, P.G.; et al. Molecular basis for universal HLA-A*0201-restricted CD8+ T-cell immunity against influenza viruses. Proc. Natl. Acad. Sci. USA 2016, 113, 4440-4445. [CrossRef]

49. Adams, E.J.; Chien, Y.H.; Garcia, K.C. Structure of a gammadelta T cell receptor in complex with the nonclassical MHC T22. Science 2005, 308, 227. [CrossRef]

50. Luoma, A.M.; Castro, C.D.; Mayassi, T.; Bembinster, L.A.; Bai, L.; Picard, D.; Anderson, B.; Scharf, L.; Kung, J.E.; Sibener, L.V.; et al. Crystal structure of Vdelta1 $\mathrm{T}$ cell receptor in complex with CD1d-sulfatide shows MHC-like recognition of a self-lipid by human gammadelta T cells. Immunity 2013, 39, 1032. [CrossRef]

51. Uldrich, A.P.; Le Nours, J.; Pellicci, D.G.; Gherardin, N.A.; McPherson, K.G.; Lim, R.T.; Patel, O.; Beddoe, T.; Gras, S.; Rossjohn, J.; et al. CD1d-lipid antigen recognition by the gammadelta TCR. Nat. Immunol. 2013, 14, 1137. [CrossRef]

52. Vantourout, P.; Hayday, A. Six-of-the-best: Unique contributions of gammadelta T cells to immunology. Nat. Rev. Immunol. 2013, 13, 88. [CrossRef]

53. Legut, M.; Cole, D.K.; Sewell, A.K. The promise of gammadelta T cells and the gammadelta T cell receptor for cancer immunotherapy. Cell Mol. Immunol. 2015, 12, 656. [CrossRef]

54. Rigau, M.; Ostrouska, S.; Fulford, T.S.; Johnson, D.N.; Woods, K.; Ruan, Z.; McWilliam, H.E.G.; Hudson, C.; Tutuka, C.; Wheatley, A.K.; et al. Butyrophilin 2A1 is essential for phosphoantigen reactivity by gammadelta T cells. Science 2020, 367, 6478. [CrossRef] [PubMed]

55. Adams, E.J.; Gu, S.; Luoma, A.M. Human gamma delta T cells: Evolution and ligand recognition. Cell. Immunol. 2015, 296, 31-40. [CrossRef] [PubMed]

56. Stone, J.D.; Chervin, A.S.; Kranz, D.M. T-cell receptor binding affinities and kinetics: Impact on T-cell activity and specificity. Immunology 2008, 126, 165-176. [CrossRef] [PubMed]

57. Adams, J.J.; Narayanan, S.; Liu, B.; Birnbaum, M.E.; Kruse, A.C.; Bowerman, N.A.; Chen, W.; Levin, A.M.; Connolly, J.M.; Zhu, C.; et al. T cell receptor signaling is limited by docking geometry to peptide-major histocompatibility complex. Immunity 2011, 35, 681-693. [CrossRef] [PubMed]

58. Holler, P.D.; Kranz, D.M. Quantitative analysis of the contribution of TCR/pepMHC affinity and CD8 to T cell activation. Immunity 2003, 18, 255-264. [CrossRef]

59. Kerry, S.E.; Buslepp, J.; Cramer, L.A.; Maile, R.; Hensley, L.L.; Nielsen, A.I.; Kavathas, P.; Vilen, B.J.; Collins, E.J.; Frelinger, J.A. Interplay between TCR affinity and necessity of coreceptor ligation: High-affinity peptide-MHC/TCR interaction overcomes lack of CD8 engagement. J. Immunol. 2003, 171, 4493-4503. [CrossRef] [PubMed]

60. Govern, C.C.; Paczosa, M.K.; Chakraborty, A.K.; Huseby, E.S. Fast on-rates allow short dwell time ligands to activate T cells. Proc. Natl. Acad. Sci. USA 2010, 107, 8724-8729. [CrossRef] [PubMed]

61. Huang, J.; Zarnitsyna, V.I.; Liu, B.; Edwards, L.J.; Jiang, N.; Evavold, B.D.; Zhu, C. The kinetics of two-dimensional TCR and pMHC interactions determine T-cell responsiveness. Nat. Cell Biol. 2010, 464, 932-936. [CrossRef] [PubMed]

62. Aleksic, M.; Dushek, O.; Zhang, H.; Shenderov, E.; Chen, J.-L.; Cerundolo, V.; Coombs, D.; Van Der Merwe, P. Dependence of T cell antigen recognition on T cell receptor-peptide MHC confinement time. Immunity 2010, 32, 163-174. [CrossRef] [PubMed]

63. Klammt, C.; Novotná, L.; Li, D.T.; Wolf, M.; Blount, A.L.; Zhang, K.; Fitchett, J.R.; Lillemeier, B.F. T cell receptor dwell times control the kinase activity of Zap70. Nat. Immunol. 2015, 16, 961-969. [CrossRef] [PubMed]

64. Kim, S.T.; Takeuchi, K.; Sun, Z.Y.; Touma, M.; Castro, C.E.; Fahmy, A.; Lang, M.J.; Wagner, G.; Reinherz, E.L. The alphabeta T cell receptor is an anisotropic mechanosensor. J. Biol. Chem. 2009, 284, 31028. [CrossRef] [PubMed]

65. Liu, B.; Chen, W.; Evavold, B.D.; Zhu, C. Accumulation of dynamic catch bonds between TCR and agonist peptide-MHC triggers T cell signaling. Cell 2014, 157, 357-368. [CrossRef] [PubMed]

66. Hong, J.; Persaud, S.P.; Horvath, S.; Allen, P.M.; Evavold, B.D.; Zhu, C. Force-regulated in situ TCR-peptide-bound MHC class II kinetics determine functions of CD4+ T cells. J. Immunol. 2015, 195, 3557-3564. [CrossRef]

67. Ekim, S.T.; Eshin, Y.; Ebrazin, K.; Mallis, R.J.; Sun, Z.-Y.J.; Wagner, G.; Lang, M.J.; Reinherz, E.L. TCR mechanobiology: Torques and tunable structures linked to early T cell signaling. Front. Immunol. 2012, 3, 76. [CrossRef]

68. Liu, Y.; Blanchfield, L.; Ma, V.P.-Y.; Andargachew, R.; Galior, K.; Liu, Z.; Evavold, B.; Salaita, K. DNA-based nanoparticle tension sensors reveal that $\mathrm{T}$-cell receptors transmit defined $\mathrm{pN}$ forces to their antigens for enhanced fidelity. Proc. Natl. Acad. Sci. USA 2016, 113, 5610-5615. [CrossRef]

69. Mcmahan, R.H.; McWilliams, J.A.; Jordan, K.R.; Dow, S.W.; Wilson, D.B.; Slansky, J.E. Relating TCR-peptide-MHC affinity to immunogenicity for the design of tumor vaccines. J. Clin. Investig. 2006, 116, 2543-2551. [CrossRef]

70. Schmid, D.A.; Irving, M.B.; Posevitz, V.; Hebeisen, M.; Posevitz-Fejfar, A.; Sarria, J.-C.F.; Gomez-Eerland, R.; Thome, M.; Schumacher, T.N.M.; Romero, P.; et al. Evidence for a TCR affinity threshold delimiting maximal CD8 T cell function. J. Immunol. 2010, 184, 4936-4946. [CrossRef]

71. Gálvez, J.; Gálvez, J.J.; García-Peñarrubia, P. Is TCR/pMHC affinity a good estimate of the T-cell response? An answer based on predictions from 12 phenotypic models. Front. Immunol. 2019, 10, 349. [CrossRef]

72. Busch, D.H.; Pamer, E. T cell affinity maturation by selective expansion during infection. J. Exp. Med. 1999, 189, 701-710. [CrossRef] [PubMed]

73. Malherbe, L.; Hausl, C.; Teyton, L.; McHeyzer-Williams, M.G. Clonal selection of helper T cells is determined by an affinity threshold with no further skewing of TCR binding properties. Immunity 2004, 21, 669-679. [CrossRef] [PubMed] 
74. Zehn, D.; Lee, S.Y.; Bevan, M.J. Complete but curtailed T-cell response to very low-affinity antigen. Nat. Cell Biol. 2009, 458, 211-214. [CrossRef] [PubMed]

75. Bentzen, A.K.; Marquard, A.M.; Lyngaa, R.B.; Saini, S.K.; Ramskov, S.; Donia, M.; Such, L.; Furness, A.J.S.; McGranahan, N.; Rosenthal, R.; et al. Large-scale detection of antigen-specific T cells using peptide-MHC-I multimers labeled with DNA barcodes. Nat. Biotechnol. 2016, 34, 1037-1045. [CrossRef]

76. Sibener, L.V.; Fernandes, R.A.; Kolawole, E.M.; Carbone, C.B.; Liu, F.; McAffee, D.; Birnbaum, M.E.; Yang, X.; Su, L.F.; Yu, W.; et al. Isolation of a structural mechanism for uncoupling $\mathrm{T}$ cell receptor signaling from peptide-MHC binding. Cell 2018, 174, 672-687.e27. [CrossRef]

77. Harndahl, M.; Rasmussen, M.; Røder, G.; Pedersen, I.D.; Sørensen, M.; Nielsen, M.; Buus, S. Peptide-MHC class I stability is a better predictor than peptide affinity of CTL immunogenicity. Eur. J. Immunol. 2012, 42, 1405-1416. [CrossRef] [PubMed]

78. Van Der Burg, S.H.; Visseren, M.J.; Brandt, R.M.; Kast, W.M.; Melief, C.J. Immunogenicity of peptides bound to MHC class I molecules depends on the MHC-peptide complex stability. J. Immunol. 1996, 156, 3308-3314.

79. Busch, D.H.; Pamer, E.G. MHC class I/peptide stability: Implications for immunodominance, in vitro proliferation, and diversity of responding CTL. J. Immunol. 1998, 160, 4441-4448.

80. Rasmussen, M.; Fenoy, E.; Harndahl, M.; Kristensen, A.B.; Nielsen, I.K.; Nielsen, M.; Buus, S. Pan-specific prediction of peptide-MHC class I complex stability, a correlate of T cell immunogenicity. J. Immunol. 2016, 197, 1517-1524. [CrossRef]

81. Nicholls, S.; Piper, K.P.; Mohammed, F.; Dafforn, T.R.; Tenzer, S.; Salim, M.; Mahendra, P.; Craddock, C.; Van Endert, P.; Schild, H.; et al. Secondary anchor polymorphism in the HA-1 minor histocompatibility antigen critically affects MHC stability and TCR recognition. Proc. Natl. Acad. Sci. USA 2009, 106, 3889-3894. [CrossRef]

82. Lazarski, C.A.; Chaves, F.A.; Jenks, S.A.; Wu, S.; Richards, K.A.; Weaver, J.; Sant, A.J. The kinetic stability of MHC class II: Peptide complexes is a key parameter that dictates immunodominance. Immunity 2005, 23, 29-40. [CrossRef]

83. Spierings, E.; Gras, S.; Reiser, J.-B.; Mommaas, B.; Almekinders, M.; Kester, M.G.D.; Chouquet, A.; Le Gorrec, M.; Drijfhout, J.W.; Ossendorp, F; et al. Steric hindrance and fast dissociation explain the lack of immunogenicity of the minor histocompatibility HA-1Arg null allele. J. Immunol. 2009, 182, 4809-4816. [CrossRef]

84. Gottschalk, R.A.; Hathorn, M.M.; Beuneu, H.; Corse, E.; Dustin, M.L.; Altan-Bonnet, G.; Allison, J.P. Distinct influences of peptide-MHC quality and quantity on in vivo T-cell responses. Proc. Natl. Acad. Sci. USA 2012, 109, 881-886. [CrossRef] [PubMed]

85. Calis, J.J.A.; Maybeno, M.; Greenbaum, J.A.; Weiskopf, D.; De Silva, A.D.; Sette, A.; Keşmir, C.; Peters, B. Properties of MHC class I presented peptides that enhance immunogenicity. PLoS Comput. Biol. 2013, 9, e1003266. [CrossRef] [PubMed]

86. Coles, C.H.; Mulvaney, R.M.; Malla, S.; Walker, A.; Smith, K.J.; Lloyd, A.; Lowe, K.L.; McCully, M.L.; Hague, R.M.; Aleksic, M.; et al. TCRs with distinct specificity profiles use different binding modes to engage an identical peptide-HLA complex. J. Immunol. 2020, 204, 1943-1953. [CrossRef] [PubMed]

87. Fodor, J.; Riley, B.T.; Borg, N.A.; Buckle, A.M. Previously hidden dynamics at the TCR-peptide-MHC interface revealed. J. Immunol. 2018, 200, 4134. [CrossRef] [PubMed]

88. Dong, D.; Zheng, L.; Lin, J.; Zhang, B.; Zhu, Y.; Li, N.; Xie, S.; Wang, Y.; Gao, N.; Huang, Z. Structural basis of assembly of the human T cell receptor-CD3 complex. Nat. Cell Biol. 2019, 573, 546-552. [CrossRef]

89. Dash, P.; Fiore-Gartland, A.J.; Hertz, T.; Wang, G.C.; Sharma, S.; Souquette, A.; Crawford, J.C.; Clemens, E.B.; Nguyen, T.H.O.; Kedzierska, K.; et al. Quantifiable predictive features define epitope-specific T cell receptor repertoires. Nat. Cell Biol. 2017, 547, 89-93. [CrossRef]

90. Ding, Y.H.; Smith, K.J.; Garboczi, D.N.; Utz, U.; Biddison, W.E.; Wiley, D.C. Two human T cell receptors bind in a similar diagonal mode to the HLA-A2/Tax peptide complex using different TCR amino acids. Immunity 1998, 8, 403-411. [CrossRef]

91. Garcia, K.C.; Degano, M.; Pease, L.R.; Huang, M.; Peterson, P.A.; Teyton, L.; Wilson, I.A. Structural basis of plasticity in T cell receptor recognition of a self peptide-MHC antigen. Science 1998, 279, 1166-1172. [CrossRef]

92. Reiser, J.-B.; Darnault, C.; Guimezanes, A.; Grégoire, C.; Mosser, T.; Schmitt-Verhulst, A.-M.; Fontecilla-Camps, J.C.; Malissen, B.; Housset, M.; Mazza, G. Crystal structure of a T cell receptor bound to an allogeneic MHC molecule. Nat. Immunol. 2000, 1, 291-297. [CrossRef] [PubMed]

93. Reiser, J.B.; Grégoire, C.; Darnault, C.; Mosser, T.; Guimezanes, A.; Schmitt-Verhulst, A.-M.; Fontecilla-Camps, J.C.; Mazza, G.; Malissen, B.; Housset, D. A T cell receptor CDR3beta loop undergoes conformational changes of unprecedented magnitude upon binding to a peptide/MHC class I complex. Immunity 2002, 16, 345-354. [CrossRef]

94. Buslepp, J.; Wang, H.; Biddison, W.E.; Appella, E.; Collins, E.J. A correlation between TCR Valpha docking on MHC and CD8 dependence: Implications for T cell selection. Immunity 2003, 19, 595. [CrossRef]

95. Tynan, F.E.; Burrows, S.R.; Buckle, A.M.; Clements, C.S.; Borg, N.A.; Miles, J.J.; Beddoe, T.; Whisstock, J.C.; Wilce, J.A.; Silins, S.L.; et al. T cell receptor recognition of a 'super-bulged' major histocompatibility complex class I-bound peptide. Nat. Immunol. 2005, 6, 1114-1122. [CrossRef] [PubMed]

96. Chen, J.-L.; Stewart-Jones, G.; Bossi, G.; Lissin, N.M.; Wooldridge, L.; Choi, E.M.L.; Held, G.; Dunbar, P.R.; Esnouf, R.M.; Sami, M.; et al. Structural and kinetic basis for heightened immunogenicity of T cell vaccines. J. Exp. Med. 2005, 201, 1243-1255. [CrossRef]

97. Hoare, H.L.; Sullivan, L.C.; Pietra, G.; Clements, C.S.; Lee, E.J.; Ely, L.K.; Beddoe, T.; Falco, M.; Kjer-Nielsen, L.; Reid, H.H.; et al. Structural basis for a major histocompatibility complex class Ib-restricted T cell response. Nat. Immunol. 2006, 7, 256-264. [CrossRef] 
98. Tynan, F.E.; Reid, H.H.; Kjer-Nielsen, L.; Miles, J.J.; Wilce, M.C.J.; Kostenko, L.; Borg, N.A.; Williamson, N.A.; Beddoe, T.; Purcell, A.W.; et al. A T cell receptor flattens a bulged antigenic peptide presented by a major histocompatibility complex class I molecule. Nat. Immunol. 2007, 8, 268-276. [CrossRef]

99. Colf, L.A.; Bankovich, A.J.; Hanick, N.A.; Bowerman, N.A.; Jones, L.L.; Kranz, D.M.; Garcia, K.C. How a single T cell receptor recognizes both self and foreign MHC. Cell 2007, 129, 135-146. [CrossRef]

100. Mazza, C.; Auphan-Anezin, N.; Grégoire, C.; Guimezanes, A.; Kellenberger, C.; Roussel, A.; Kearney, A.; Van Der Merwe, P.A.; Schmitt-Verhulst, A.-M.; Malissen, B. How much can a T-cell antigen receptor adapt to structurally distinct antigenic peptides? EMBO J. 2007, 26, 1972-1983. [CrossRef]

101. Archbold, J.K.; Macdonald, W.A.; Gras, S.; Ely, L.K.; Miles, J.J.; Bell, M.J.; Brennan, R.M.; Beddoe, T.; Wilce, M.C.; Clements, C.S.; et al. Natural micropolymorphism in human leukocyte antigens provides a basis for genetic control of antigen recognition. J. Exp. Med. 2009, 206, 209-219. [CrossRef]

102. Gras, S.; Burrows, S.R.; Kjer-Nielsen, L.; Clements, C.S.; Liu, Y.C.; Sullivan, L.C.; Bell, M.J.; Brooks, A.G.; Purcell, A.W.; McCluskey, J.; et al. The shaping of T cell receptor recognition by self-tolerance. Immunity 2009, 30, 193-203. [CrossRef] [PubMed]

103. Cole, D.K.; Yuan, F.; Rizkallah, P.J.; Miles, J.J.; Gostick, E.; Price, D.A.; Gao, G.F.; Jakobsen, B.K.; Sewell, A.K. Germ line-governed recognition of a cancer epitope by an immunodominant human T-cell receptor. J. Biol. Chem. 2009, 284, 27281-27289. [CrossRef] [PubMed]

104. Gras, S.; Chen, Z.; Miles, J.J.; Liu, Y.C.; Bell, M.J.; Sullivan, L.C.; Kjer-Nielsen, L.; Brennan, R.M.; Burrows, J.M.; Neller, M.A.; et al Allelic polymorphism in the T cell receptor and its impact on immune responses. J. Exp. Med. 2010, 207, 1555-1567. [CrossRef] [PubMed]

105. Miles, J.J.; Bulek, A.M.; Cole, D.K.; Gostick, E.; Schauenburg, A.J.A.; Dolton, G.; Venturi, V.; Davenport, M.P.; Tan, M.P.; Burrows, S.R.; et al. Genetic and structural basis for selection of a ubiquitous T cell receptor deployed in Epstein-Barr virus infection. PLoS Pathog. 2010, 6, e1001198. [CrossRef]

106. Day, E.B.; Guillonneau, C.; Gras, S.; La Gruta, N.L.; Vignali, D.A.A.; Doherty, P.C.; Purcell, A.W.; Rossjohn, J.; Turner, S.J. Structural basis for enabling T-cell receptor diversity within biased virus-specific CD8+ T-cell responses. Proc. Natl. Acad. Sci. USA 2011, 108, 9536-9541. [CrossRef]

107. Borbulevych, O.Y.; Santhanagopolan, S.M.; Hossain, M.; Baker, B.M. TCRs used in cancer gene therapy cross-react with MART1/Melan-A tumor antigens via distinct mechanisms. J. Immunol. 2011, 187, 2453-2463. [CrossRef] [PubMed]

108. Yin, L.; Huseby, E.; Scott-Browne, J.; Rubtsova, K.; Pinilla, C.; Crawford, F.; Marrack, P.; Dai, S.; Kappler, J.W. A single T cell receptor bound to major histocompatibility complex class I and class II glycoproteins reveals switchable TCR conformers. Immunity 2011, 35, 23-33. [CrossRef] [PubMed]

109. Stewart-Jones, G.B.; Simpson, P.; Van Der Merwe, P.A.; Easterbrook, P.; McMichael, A.J.; Rowland-Jones, S.L.; Jones, E.Y.; Gillespie, G.M. Structural features underlying T-cell receptor sensitivity to concealed MHC class I micropolymorphisms. Proc. Natl. Acad. Sci. USA 2012, 109, E3483-E3492. [CrossRef]

110. Gras, S.; Wilmann, P.G.; Chen, Z.; Halim, H.; Liu, Y.C.; Kjer-Nielsen, L.; Purcell, A.W.; Burrows, S.R.; McCluskey, J.; Rossjohn, J. A structural basis for varied alphabeta TCR usage against an immunodominant EBV antigen restricted to a HLA-B8 molecule. J. Immunol. 2012, 188, 311. [CrossRef] [PubMed]

111. Shimizu, A.; Kawana-Tachikawa, A.; Yamagata, A.; Han, C.; Zhu, D.; Sato, Y.; Nakamura, H.; Koibuchi, T.; Carlson, J.; Martin, E.; et al. Structure of TCR and antigen complexes at an immunodominant CTL epitope in HIV-1 infection. Sci. Rep. 2013, 3, 3097. [CrossRef] [PubMed]

112. Ladell, K.; Hashimoto, M.; Iglesias, M.C.; Wilmann, P.G.; McLaren, J.E.; Gras, S.; Chikata, T.; Kuse, N.; Fastenackels, S.; Gostick, E.; et al. A molecular basis for the control of preimmune escape variants by HIV-Specific CD8+ T cells. Immunity 2013, 38, 425-436. [CrossRef] [PubMed]

113. Liu, Y.C.; Miles, J.J.; Neller, M.A.; Gostick, E.; Price, D.A.; Purcell, A.W.; McCluskey, J.; Burrows, S.R.; Rossjohn, J.; Gras, S. Highly divergent T-cell Receptor binding modes underlie specific recognition of a bulged viral peptide bound to a human leukocyte antigen class I molecule. J. Biol. Chem. 2013, 288, 15442-15454. [CrossRef] [PubMed]

114. Motozono, C.; Kuse, N.; Sun, X.; Rizkallah, P.J.; Fuller, A.; Oka, S.; Cole, D.K.; Sewell, A.K.; Takiguchi, M. Molecular basis of a dominant $\mathrm{T}$ cell response to an HIV reverse transcriptase 8-mer epitope presented by the protective allele HLA-B*51:01. J. Immunol. 2014, 192, 3428-3434. [CrossRef] [PubMed]

115. Nivarthi, U.K.; Gras, S.; Kjer-Nielsen, L.; Berry, R.; Lucet, I.S.; Miles, J.J.; Tracy, S.L.; Purcell, A.W.; Bowden, D.S.; Hellard, M.; et al. An extensive antigenic footprint underpins immunodominant TCR adaptability against a hypervariable viral determinant. $J$. Immunol. 2014, 193, 5402-5413. [CrossRef] [PubMed]

116. Sullivan, L.C.; Walpole, N.G.; Farenc, C.; Pietra, G.; Sum, M.J.W.; Clements, C.S.; Lee, E.J.; Beddoe, T.; Falco, M.; Mingari, M.C.; et al. A conserved energetic footprint underpins recognition of human leukocyte antigen-E by two distinct alphabeta $\mathrm{T}$ cell receptors. J. Biol. Chem. 2017, 292, 21149. [CrossRef] [PubMed]

117. Cole, D.K.; Berg, H.A.V.D.; Lloyd, A.; Crowther, M.D.; Beck, K.; Ekeruche-Makinde, J.; Miles, J.J.; Bulek, A.M.; Dolton, G.; Schauenburg, A.J.; et al. Structural mechanism underpinning cross-reactivity of a CD8+T-cell clone that recognizes a peptide derived from human telomerase reverse transcriptase. J. Biol. Chem. 2017, 292, 802-813. [CrossRef] 
118. Cole, D.K.; Fuller, A.; Dolton, G.; Zervoudi, E.; Legut, M.; Miles, K.; Blanchfield, L.; Madura, F.; Holland, C.J.; Bulek, A.M.; et al. Dual molecular mechanisms govern escape at immunodominant HLA A2-restricted HIV epitope. Front. Immunol. 2017, 8, 1503. [CrossRef]

119. Duru, A.D.; Sun, R.; Allerbring, E.B.; Chadderton, J.; Kadri, N.; Han, X.; Peqini, K.; Uchtenhagen, H.; Madhurantakam, C.; Pellegrino, S.; et al. Tuning antiviral CD8 T-cell response via proline-altered peptide ligand vaccination. PLoS Pathog. 2020, 16, e1008244. [CrossRef]

120. Holland, C.J.; Crean, R.M.; Pentier, J.M.; De Wet, B.; Lloyd, A.; Srikannathasan, V.; Lissin, N.; Lloyd, K.A.; Blicher, T.H.; Conroy, P.J.; et al. Specificity of bispecific T cell receptors and antibodies targeting peptide-HLA. J. Clin. Investig. 2020, 130, 2673-2688. [CrossRef]

121. Wu, D.; Gallagher, D.T.; Gowthaman, R.; Pierce, B.G.; Mariuzza, R.A. Structural basis for oligoclonal T cell recognition of a shared p53 cancer neoantigen. Nat. Commun. 2020, 11, 2908. [CrossRef]

122. Rowntree, L.C.; Nguyen, T.H.; Farenc, C.; Halim, H.; Hensen, L.; Rossjohn, J.; Kotsimbos, T.C.; Purcell, A.W.; Kedzierska, K.; Gras, S.; et al. A shared TCR bias toward an immunogenic EBV epitope dominates in HLA-B*07:02-expressing individuals. J. Immunol. 2020, 205, 1524-1534. [CrossRef] [PubMed]

123. Coles, C.H.; Mcmurran, C.; Lloyd, A.; Hock, M.; Hibbert, L.; Raman, M.C.C.; Hayes, C.; Lupardus, P.; Cole, D.K.; Harper, S. T cell receptor interactions with human leukocyte antigen govern indirect peptide selectivity for the cancer testis antigen MAGE-A4. J. Biol. Chem. 2020, 295, 11486-11494. [CrossRef] [PubMed]

124. Rossjohn, J.; Gras, S.; Miles, J.J.; Turner, S.J.; Godfrey, D.I.; McCluskey, J. T Cell antigen receptor recognition of antigen-presenting molecules. Annu. Rev. Immunol. 2015, 33, 169-200. [CrossRef] [PubMed] 